\title{
The Sargasso Sea
}

\section{An Innovative Approach to Governance in Areas beyond National Jurisdiction}

\author{
Kristina M. Gjerde and Ole Varmer
}

A leader takes people where they want to go. A great leader takes people where they don't necessarily want to go, but ought to be. $\sim^{1}$

\section{Introduction}

In 2009, a small group of individuals launched the Sargasso Sea Alliance (ssA or Alliance) as an informal initiative to protect an iconic high seas ecosystem in the North Atlantic Ocean. ${ }^{2}$ The Alliance was designed to test the key question raised during discussions at the United Nations (UN) as to whether better implementation of existing agreements could suffice to improve the conservation and sustainable use of marine biodiversity in areas beyond national

1 Acknowledgements: The authors would like to thank David Freestone for his extensive contribution to the development of international law and policy and particularly for his help in reviewing this chapter to make it a more accurate account of the great body of his work in protecting the Sargasso Sea. The authors would also like to thank Katherine Liljestrand, Legal Intern for NOAA Office of General Council in the summer of 2018 while a student at Georgetown Law School. Any inaccuracies, however, should be attributed to the authors.

Quote by Rosalynn Carter in K Goldin, 'Great Leaders Take People Where They May Not Want to Go' Forbes (1 October 2018), https://www.forbes.com/sites/karagoldin/2018/10/ o1/great-leaders-take-people-where-they-may-not-want-to-go/\#49ccd4b21421; all websites accessed 12 October unless otherwise noted.

2 David Freestone participated in the 2009 founding workshop of the Sargasso Sea Alliance. Other participants included Jeff Ardron, Laura Cassiani, Billy Causey, Eden Charles, Sylvia A Earle, Kristina M Gjerde, Arlo Hemphill, Dan Laffoley, Sheila McKenna, Fred W Ming, Conn Nugent, Howard Roe, Phillippe M Rouja, Dire Tladi, Tammy Trott, Teddy Tucker, Charlotte Vick, and Mirella von Lindenfels. Many remain key partners and collaborators for which the authors are grateful. 
jurisdiction $(\mathrm{ABNJ})$ or whether a new international agreement was warranted. ${ }^{3}$ While significant progress has been made, it is fair to say that the experiences of the Sargasso Sea Alliance served to inform the decision to launch negotiations towards such an international agreement in $2015,{ }^{4}$ and can hopefully continue to serve as a source of inspiration for the future direction of high seas governance.

The term 'governance' is used broadly here to include the existing international law applicable to ABNJ, particularly the 1982 United Nations Convention on the Law of the Sea (LOSC $)^{5}$ as well as the 'structures and processes that are

3 See KM Gjerde, 'Perspectives on a Developing Regime for Marine Biodiversity Conservation and Sustainable Use beyond National Jurisdiction' in HN Scheiber, N Oral and M-S Kwon (eds), Ocean Law Debates: The 5o-Year Legacy and Emerging Issues for the Years Ahead (Brill, 2015) 354-380. The need to improve the conservation and sustainable use of marine biodiversity in areas beyond national jurisdiction $(\mathrm{ABNJ})$ first came to the attention of the United Nations (UN) in 2002, which resulted in the launch, in 2006, of a UN informal ad hoc working group to study issues related to the conservation and sustainable use of marine biodiversity in ABNJ. To help advance these studies, Freestone joined Gjerde as one of four co-chairs at a 2007 IUCN Workshop on High Seas Governance for the 21st Century (with Rosemary Rayfuse and Robin Warner) that considered a range of short-, medium- and longer-term measures to achieve effective protection and sustainable use in $\mathrm{ABNJ}$, including through pilot high seas marine protected areas such as for the Sargasso Sea. After many years of discussion of options through an informal UN Working Group, in 2015 governments formally agreed on the need for a new international legally binding instrument on conservation and sustainable use and launched a two-year preparatory process.

4 G Wright, J Rochette, K Gjerde and I Seeger, The Long and Winding Road:Negotiating a Treaty for the Conservation and Sustainable Use of Marine Biodiversity in Areas beyond National Jurisdiction, IDDRI Study No o8/18 (Institute for Sustainable Development and International Relations, 2018), https://www.iddri.org/en/publications-and-events/study/long-andwinding-road-negotiating-high-seas-treaty. Negotiations for a binding international agreement for marine biodiversity in ABNJ ('BBNJ agreement') were finally launched in 2017 by UNGA Resolution 69/292 to address, among other things, marine genetic resources including questions about sharing benefits, areas based management tools, including marine protected areas (MPAS), environmental impacts assessments (EIAS) and capacity building and transfer of marine technology. UNGA Resolution 69/292 further stipulates that the process should enhance coordination while not 'undermining' existing legal instruments and frameworks and relevant global, sectoral and regional bodies. United Nations General Assembly (UNGA), Resolution 69/292): Development of an international legally binding instrument under the United Nations Convention on the Law of the Sea on the Conservation and Sustainable Use of Marine Biological Diversity of Areas beyond National Jurisdiction, adopted 19 June 2015.

5 Adopted 1o December 1982, in force 16 November 1994, 1833 UNTS 3 (LOSC). On the issue of implementation and/or modification of the LOSC, see D Freestone and AG Oude Elferink, 'Flexibility and Innovation in the Law of the Sea: Will the Los Convention Amendment Procedures Ever be Used?' in AG Oude Elferink (ed), Stability and Change in the Law of the Sea: The Role of the LOS Convention (Martinus Nijhoff, 2005)169-221, 184-19o. 
designed to ensure accountability, transparency, responsiveness, rule of law, stability, equity and inclusiveness, empowerment, and broad-based participation.' ${ }^{6}$ Thus 'governance' goes beyond the relevant legal instruments and institutions to include how and by whom these laws are administered and whether the processes ensure equitable, inclusive and ecologically sustainable results. The term 'Sargasso Sea' is used here to refer to the vast majority of the Sargasso Sea that lies beyond national jurisdiction where international cooperation is essential for managing human activities in the high seas water column and the international seabed Area below. While the Sargasso Sea itself surrounds the islands of Bermuda and extends into the exclusive economic zones (EEZs) of several Caribbean States and the United States, the focus in this chapter is on the frontier efforts to improve the governance and conservation of marine biodiversity and ecosystems beyond national jurisdiction (BBNJ).

This chapter takes a personal approach by recounting how, under the pioneering leadership of Professor David Freestone, the Sargasso Sea Alliance evolved from an informal initiative to test the rules governing the high seas frontier to the formal Sargasso Sea Commission (ssc) established pursuant to the Hamilton Declaration signed by five Government Signatories in 2014. By doing so, it seeks to honour Freestone's productive career in tackling new frontiers of international law as both an academic observer ${ }^{7}$ and an active participant.

In 2010, Freestone stepped into the role of Executive Director of the SSA, then a nascent partnership composed of the International Union for Conservation of Nature (IUCN) and its World Commission on Protected Areas (WCPA), nongovernmental organizations ( $\mathrm{NGOS}$ ), and scientists, led and supported by the Government of Bermuda, in its capacity as a self-governing British Overseas Territory. ${ }^{8}$ As further explored herein, through a combination of science, law and diplomatic finesse, Freestone transformed the ssA into an innovative mechanism for advancing the stewardship, precaution, and science-based management principles he has long espoused for the high seas. ${ }^{9}$ The Sargasso

6 'In a broad sense, governance is about the culture and institutional environment in which citizens and stakeholders interact among themselves and participate in public affairs'. UNEsco, 'Concept of Governance', International Bureau of Education, http://www.ibe.unesco. org/en/geqaf/technical-notes/concept-governance.

7 See D Freestone, 'An Unfinished Agenda' in J Barrett and R Barnes (eds), Law of the Sea: UNCLOS as a Living Instrument (BIICL, 2016) 231-266.

8 As a self-governing British Overseas Territory, the Government of Bermuda enjoys a degree of external authority. See I Hendry and S Dickson, British Overseas Territories Law (Hart, 2018), passim and especially $268-270$.

9 D Freestone, 'Modern Principles of High Seas Governance: The Legal Underpinnings' (2009) 39(1) Environmental Policy and Law 44-49. 
Sea initiative has since emerged as a template for an innovative public-private partnership approach in which governments, scientists, intergovernmental and non-governmental organizations and other private persons and institutions cooperate as stewards to bring more responsive governance and conservation for iconic areas of the global commons. ${ }^{10}$

This chapter describes the history of this unique public-private partnership approach by exploring, in Sections $2-5$, the special nature of the Sargasso Sea, the leaders who have championed its protection, the establishment of the SSA, and the SsA's transformation into the ssc through the Hamilton Declaration. Section 6 details the ssc activities which, under the guidance of Freestone, seek to improve the management, conservation, and governance of this significant sea area. Section 7 draws some lessons learned. ${ }^{11}$ Sections 8 and 9 offer some recommendations, based on Freestone's work, ${ }^{12}$ for consideration by the international community as it deliberates the content of the B BNJ Agreement ${ }^{13}$ and the future of the Sargasso Sea initiative.

This chapter concludes with the observation that public-private partnerships can play an essential role in fostering stewardship in remote frontiers, as demonstrated by Freestone's achievements in the Sargasso Sea. Nevertheless, to accelerate progress despite the 'persistent resistance to precaution' encountered by the Alliance in seeking protective measures through existing sectoral organizations, ${ }^{14}$ three elements are still needed: (1) clear legal obligations to protect, conserve and sustain marine biodiversity based on science and the precautionary principle, (2) a global process to establish high seas marine

10 D Freestone and F Bulger, 'The Sargasso Sea Commission: An Innovative Approach to the Conservation of Areas beyond National Jurisdiction' (2016) 30 Ocean Yearbook 80-9o.

11 D Freestone and K Gjerde, Lessons from the Sargasso Sea. Challenges to the Conservation and Sustainable Use of Marine Biodiversity beyond National Jurisdiction (IUCN and Sargasso Sea Commission, 2016), http://www.un.org/depts/los/biodiversity/prepcom_ files/Sargasso_Sea_Commission_Lessons_Learned.pdf.

12 D Freestone, 'Taking the Hamilton Declaration to the Next Level' (2018), http://www.sargassoseacommission.org/storage/Taking_the_Hamilton_Declaration_to_the_next_level_ _11_2018.pdf; D Balton, Next Steps To Strengthen Stewardship of the Sargasso Sea, report prepared for the Workshop and Fourth Joint Meeting of the Sargasso Sea Commission and Hamilton Declaration Signatories, Bermuda Institute for Ocean Sciences, St George's, Bermuda, March 2019, http://www.sargassoseacommission.org/storage/Strengthening Stewardship_of_the_Sargasso_Sea.pdf.

13 United Nations General Assembly, Draft text of an agreement under the United Nations Convention on the Law of the Sea on the conservation and sustainable use of marine biological diversity of areas beyond national jurisdiction (вBNJ Agreement), UN Doc A/ CONF.232/2019/6 (17 May 2019).

14 Freestone and Gjerde, Lessons, above (n 11). 
protected areas (MPAs) together with protective measures applicable to all State Parties, and (3) strengthened global, regional and sub-regional institutions to enhance accountability, transparency, responsiveness and inclusiveness. ${ }^{15}$ A robust BBNJ Agreement based on lessons derived from the Sargasso Sea initiative can thus play a transformative role in how we manage and govern our common ocean. First, however, we want to remind our readers of the many ways the Sargasso Sea is important to the environment and world economy, ${ }^{16}$ and why this special area illustrates the need for improved governance and stewardship of marine biodiversity in ABNJ.

Environmental and Economic Importance of the Sargasso Sea

The Sargasso Sea is a vast area of ocean named for a genus of unique, freefloating seaweed called Sargassum. ${ }^{17}$ Unlike most seaweeds that grow and reproduce on the seabed, it is 'holopelagic', which means it grows, reproduces, and remains pelagic in the water column throughout its life. ${ }^{18}$ The Sargasso Sea is the only sea without a coast, for the Sargassum weed from which the sea gets its name is held in place by the currents of the North Atlantic, ${ }^{19}$ which

15 G Wright, K Cremers, J Rochette et al., High Hopes for the High Seas: Beyond the Package Deal towards an Ambitious Treaty, IDDRI Issue Brief No o9 (IDDRI, August 2019), https:// www.iddri.org/en/publications-and-events/issue-brief/high-hopes-high-seas-beyond -package-deal-towards-ambitious.

16 D d'A Laffoley, HSJ Roe et al., The Protection and Management of the Sargasso Sea: The Golden Floating Rainforest of the Atlantic Ocean. Summary Science and Supporting Evidence Case (Sargasso Sea Alliance, 2011) 6, 10-11.

17 See D Freestone, HSJ Roe, L Inniss, et al., 'Chapter 50: Sargasso Sea', in L Inniss and A Simcock (Joint Coordinators), First Global Integrated Marine Assessment Issued by the UN Global Reporting and Assessment of the State of the Marine Environment. UN Global Reporting and Assessment of the State of the Marine Environment First Assessment Report (United Nations, 2016), http://www.un.org/depts/los/global_reporting/WOA_RegProcess. $\mathrm{htm}$. A chapter on the Sargasso Sea will also be included in the Second Assessment.

18 AH Hemphill, 'Conservation on the High Seas: Drift Algae Habitat as an Open Ocean Cornerstone' (2005) 15(3) Parks: High Seas Marine Protected Areas 48-56, 5o, https://www. iucn.org/sites/dev/files/import/downloads/15_3_lowres.pdf.

19 The ocean currents of the Northern Atlantic Subtropical Gyre include the Gulf Stream to the west, the North Atlantic Current to the north, the Canary Current to the east, and the North Atlantic Equatorial Current to the south. The borders are dynamic, correlating roughly with the Azores High Pressure Center in any given season. See Government of Bermuda (United Kingdom) and Sargasso Sea Alliance, Sargasso Sea-Scientific Information to Describe Areas Meeting Criteria for Ecologically or Biologically Significant Marine Areas (EBSAs) (undated), https://www.oceanfdn.org/sites/default/files/EBSA_ submitted\%2B\%281\%29.compressed.pdf. 
concentrate the seaweed into large mats and windrows centred in and around the tiny islands of Bermuda. ${ }^{20}$ The Sargasso Sea spreads over more than five million square kilometers and hosts a unique community of species endemic to Sargassum. ${ }^{21}$ It provides shelter and nutrition to large numbers of threatened and endangered species, including sea turtles, as well as to commercially important species, such as wahoo, dolphinfish, tunas, and billfish. It is the only spawning place in the world for the endangered American eel (Anguilla nostrata) and the critically endangered European eel (Anguilla anguilla). ${ }^{22}$ Over thirty species of cetaceans, including humpback whales, annually migrate through the Sargasso Sea. ${ }^{23}$ Threats to the health of this unique ecosystem recounted in the Summary Science and Supporting Evidence Case by Professors Laffoley and Howard Roe include impacts from fishing, shipping, mining and other activities as well as climate change related stressors. ${ }^{24}$

An early milestone of success was the Sargasso Sea's recognition as an Ecologically or Biologically Significant Area (EBSA) under the Convention on Biological Diversity (СвD ) in 2012. ${ }^{25}$ The recognition process involves a regional expert workshop that applies scientific criteria to describe potential EBSAs followed by scrutiny by the СвD's Subsidiary Body on Scientific, Technical and Technological Advice and adoption by Parties to the СвD. ${ }^{26}$ Recognition of

20 Ibid. The Sargasso Sea is approximately $5,179,976 \mathrm{~km}^{2}$ or 2 million square miles. Bermuda, a UK territory, is in closest proximity; approximately 10 percent of the Sargasso Sea is within the Bermuda EEz $\left(464,940 \mathrm{~km}^{2}\right.$ or 179,514 miles $\left.{ }^{2}\right)$. D Freestone, 'The Sargasso Sea Alliance: An Interim Report' (2014) 44(1-2) Environmental Policy and Law 151-158.

21 Laffoley, Roe et al., above (n 16).

22 Ibid. The European eel is also on the IUCN Red list and is listed as critically endangered. See IUCN Red List, 'European Eel Anguilla anguilla', http://www.iucnredlist.org/details/ $60344 / 0$.

23 Laffoley, Roe et al., above (n 16), 20. Many of the species that frequent the Sargasso Sea are listed on the IUCN Red List and/or in the appendices of the 1973 Convention on International Trade in Endangered Species of Wild Fauna and Flora (CITES), 993 UNTS 243, or in the annexes of the 1990 Protocol concerning Specially Protected Areas and Wildlife in the Wider Caribbean Region (sPAw Protocol), 2180 UNTS 25974.

24 Laffoley, Roe et al., above (n 16).

25 Freestone and Bulger, above (n 10), 84; see also 1992 Convention on Biological Diversity (СвD), 1760 UNTS 79; СвD, Azores Scientific Criteria and Guidance for Identifying Ecologically or Biologically Significant Marine Areas and Designing Representative Networks of Marine Protected Areas in Open Ocean Waters and Deep Sea Habitats (Secretariat of the СBD, 2009), https://www.cbd.int/marine/doc/azores-brochure-en.pdf.

26 свD, ibid; see also DC Dunn, J Ardon, N Bax et al., 'The Convention on Biological Diversity's Ecologically or Biologically Significant Areas: Origins, Development, and Current Status' (2014) 49 Marine Policy 137-145; K Gjerde, LL Nordtvedt Reeve, H Harden-Davies et al., 'Protecting Earth's Last Conservation Frontier: Scientific, Management and Legal 
EBSAs is intended to provide the scientific foundation to help States and competent international organizations enhance protection of important areas of biodiversity and to inform efforts to achieve Aichi Biodiversity Target 11, which aims to have at least 10 percent of the oceans conserved, especially in areas important for ecosystem services and biodiversity, through equitable and effective management by $2020 .{ }^{27}$ More recently, the Sargasso Sea was recognized by marine experts as an example of an area likely to meet the criteria for 'outstanding universal value' used under the World Heritage Convention to inscribe World Heritage sites, were the Convention to include a process for recognizing areas beyond national jurisdiction. ${ }^{28}$

Significant progress in designating MPAs has been made by States in their $\mathrm{EEZs},{ }^{29}$ however, progress has been slower in $\mathrm{ABNJ}$ because of the cooperation needed and diverse views of some nations regarding exploitation and the need for conservation. ${ }^{30}$ Since 2007 , only seven high seas MPAs in the North East Atlantic and the two MPAs in the Southern Ocean, including the recent Ross Sea Marine Protected Area off Antarctica, have been designated, evidencing the challenges encountered in pursuing protection through regional, consensus-driven processes. ${ }^{31}$ The Sargasso Sea faces further challenges for, as

Priorities for MPAs beyond Boundaries' (2016) 26 (Suppl 2) Aquatic Conservation: Marine and Freshwater Ecosystems 45-6o.

27 Convention on Biological Diversity, 'Target 11-Technical Rationale extended (provided in document $\mathrm{COP} / 10 / \mathrm{INF} / 12 /$ Rev.1)', Strategic Goal C: To improve the status of biodiversity by safeguarding ecosystems, species and genetic diversity, https://www.cbd.int/sp/ targets/rationale/target-11/. Aichi Biodiversity Target 11 complements but is more specific than Sustainable Development Goal 14.5. Secretariat of the свD, 'Global Marine Protected Area Target of 10\% to be Achieved by 2020', Press Release (5 June 2017), https://www.cbd. int/doc/press/2017/pr-2017-o6-o5-mpa-pub-en.pdf.

28 D Freestone, D Laffoley, F Douvere and T Badman, World Heritage in the High Seas: An Idea Whose Time Has Come, World Heritage Centre Reports 44 (UNEsco, July 2016), https://www.iucn.org/news/world-heritage/2016o8/sargasso-sea-among-spots-high -seas-identified-potential-world-heritage-sites\#.

29 Within EEzs, 10.5 percent of waters are currently recognized as MPAs by the MPAtlas compared to 1.2 percent of the high seas. See the MPAtlas website, http://www.mpatlas. org/. Many States are actively participating in creating MPA s, though to varying degrees of biodiversity conservation and management. For instance, US 'MPAs' cover 25.93 percent, or 3,154,784.6 km², but a majority of these areas only target conservation of certain fish stock species or prohibit certain types of gear use. See K Liljestrand, Marine Protected Areas: State Obligations under International Law for the Conservation and Management of Marine Living Resources (in draft) (2018).

30 See Gjerde et al., above ( $\mathrm{n}_{3}$ ), for an overview of progress on MPAs in ABNJ.

31 Ibid. See also, BC Howard, 'World's Largest Marine Reserve Created Off Antarctica' National Geographic (27 October 2016), https://news.nationalgeographic.com/2016/10/ ross-sea-marine-protected-area-antarctica/ (the new 598,ooo square-mile protected area 
explored below, there is no relevant global or regional organization with a biodiversity mandate able to establish MPAs in ABNJ.

Nevertheless, the Sargasso Sea, as a recognized EBSA, is a floating bank of resources of significant economic importance and value to its users and to the world. The users directly benefiting economically from a healthy, biologically diverse ecosystem include commercial fishers, sport fishers, recreational fishers, charter operators, and commercial users of Sargassum. ${ }^{32}$ Eco-cultural tourism and other land-based industries in Bermuda that also benefit from a healthy Sargasso Sea include museums, aquariums, hotels, and restaurants. ${ }^{33}$ Incremental economic benefits come from the research, education, and tourism activities related to Sargasso Sea resources, such as marine research stations and excursions to watch birds, turtles, and whales. Though at times perceived as a nuisance, ${ }^{34}$ Sargassum also plays a role in preventing the erosion of beaches and other coastlines. Preventing this erosion can, in turn, protect coastline property values. ${ }^{35}$ The Sargasso Sea has significant socio-economic and environmental value as a unique ecosystem that provides habitats for rare and charismatic species. ${ }^{36}$ But perhaps the most important international economic benefit of the Sargasso Sea ecosystem is its sequestration of carbon

is more than twice the size of Texas, and will protect everything from penguins to whales); CM Brooks, LB Crowder, LM Curran et al., 'Science-based Management in Decline in the Southern Ocean' (2016) 354(6309) Science 185-187.

32 L Pendleton, F Krowicki, P Strosser and J Hallett-Murdoch, Assessing the Economic Contribution of Marine and Coastal Ecosystem Services in the Sargasso Sea, NI R 14-05 (Nicholas Institute for Environmental Policy Solutions, Duke University, 2014).

33 J Hallett, The Importance of the Sargasso Sea and the Offshore Waters of the Bermudian Exclusive Economic Zone to Bermuda and Its People, Sargasso Sea Alliance Science Report Series No 4 (Saragasso Sea Alliance, 2011).

34 As noted in the Sargasso Sea Commission (ssc) website, the large influxes of Sargassum weed affecting the beaches in many Caribbean areas, the coast of Brazil and even the coast of West Africa started in 2011, however the source is not suspected to be the Sargasso Sea. Rather the Sargassum weed stems from the North Equatorial Recirculation Region (NERR) south of the Sargasso Sea between the North Equatorial Current and the equator. The causes of these mass blooms and strandings are uncertain, but are thought to include increased nutrient availability from the Amazon and Orinoco Rivers, warmer surface temperatures and changes in circulation associated with climate change. ssc, 'Atlantic Sargassum Belt', http://www.sargassoseacommission.org/publications-andnews/atlantic-sargassum-belt.

35 P Walsh, C Griffiths, D Guignet and H Klemick, Adaptation, Sea Level Rise, and Property Prices in the Chesapeake Bay Watershed, National Center for Environmental Economics Working Paper 15-02 (US Environmental Protection Agency, February 2015), https://www. epa.gov/sites/production/files/2016-o3/documents/2015-02.pdf. 
dioxide, rendering it an important habitat to help address climate change. The economic value of the Sargasso Sea to the world is very difficult to quantify but is nonetheless clearly significant. The environmental and socio-economic importance of the Sargasso Sea has been recognized and championed by several individuals who were the catalysts for a new and innovative approach to care and governance.

Champions of the Sargasso Sea Ecosystem and the Sargasso Sea Alliance

Never doubt that a small group of thoughtful, committed citizens can change the world. Indeed, it is the only thing that ever has.

MARGARET MEAD

In the early $15^{\text {th }}$ century, when Portuguese sailors first encountered the large mats of floating seaweed, they called it Sargassum; the name derives from sargaço, a plant that floated in wells back home. ${ }^{37}$ The importance of the Sargasso Sea as a rare, unique ecosystem in open ocean waters has been recognized by many since that time, ${ }^{38}$ but it was Sylvia Earle who first cast this special marine area as the 'Golden Rainforest of the Ocean'. ${ }^{39}$ This led Arlo Hemphill (then working with Sylvia Earle at Conservation International and later at the Stanford Center for Ocean Solutions), Sheila McKenna (an independent scientist based in Bermuda), and Kristina Gjerde (IUCN High Seas Policy Advisor) to team up with Sylvia Earle and other partners in the IUCN WCPA Commission

37 I Armour, 'The Great Sargasso Sea' Botany Thoughts blog (2016), https://medium.com/ think-with-me/the-great-sargasso-sea-b65acao7c25d; G Gómez de Silva, Breve diccionario etimológico de la lengua española (Fondo de Cultura Económica, Mexico City, 1988) 627628 (plant in Portugal that floated in the water wells was called sargaço in Portuguese); see also Merriam Webster, 'Sargassum', https://www.merriam-webster.com/dictionary/sargassum; English Oxford Living Dictionaries, 'Sargassum', https://en.oxforddictionaries.com/ definition/sargassum. However, the Spanish word 'sargazzo' may also be a source. See ssc, 'About the Sargasso Sea: Maritime Heritage', http://www.sargassoseacommission.org/ about-the-sargasso-sea/maritime-heritage, citing Laffoley, Roe et al., above (n 16), 10-11.

38 Hemphill, above (n 18). The Sargasso Sea was singled out as an example of a unique or rare ecosystem in the Scientific Criteria adopted in 2008 by the CBD for identifying EBSAs in need of protection in open-ocean waters and deep-sea habitats. СвD, сор9 Decision IX/20: Marine and coastal biodiversity (May 2008), Annex I.

39 Mission Blue: Sylvia Earle Alliance, 'Dr. Earle Advocates for Sargasso Sea Conservation \& Bermuda Blue Halo Initiative’ Mission Blue: Sylvia Earle Alliance blog (12 June 2015), https://mission-blue.org/category/sargasso-sea/. Sylvia Earle began Mission Blue. 
on the Protected Areas High Sea Task Force in 2005 to stimulate wider interest in the Sargasso Sea as a potential high seas MPA. ${ }^{40}$ Another catalyst for the SSA occurred when Sylvia Earle and Dan Laffoley, Vice Chair Marine of the IUCN WCPA, called on the international community to cooperate in its protection of ocean 'hot spots', such as the Sargasso Sea, through a letter to 106 world leaders. ${ }^{41}$ With the timely support of the JM Kaplan Fund, the Government of Bermuda ${ }^{42}$ hosted a meeting in 2009 that led to the formal establishment of the SSA in the autumn of $2010 .^{43}$ Armed with a dazzling video message in support of the fledgling effort from the then Bermuda Premier, the Hon Dr Ewart F Brown, Earle, Laffoley and Gjerde were able to galvanize financial support and interest during the $2010 \mathrm{TED} / \mathrm{Mission}$ Blue Voyage ${ }^{44}$ to the Galapagos from future key Sargasso Sea champions Dr Richard Rockefeller and David E Shaw. ${ }^{45}$ Other financial supporters galvanized by the TED/Mission Blue expedition included Ted Waitt, Erik Gordon, and Ricardo Cisneros. Shaw and Earle became co-chairs of the ssa Steering Committee. The team was completed when Freestone was brought on board as Executive Director in October of 2010. Rockefeller was the beacon in navigating forward and a rock against adversity. Sadly, Rockefeller's life ended when his airplane crashed on 13 June 2014. He was wholeheartedly committed to this project until his untimely death, and left a legacy of outstanding philanthropy, including his efforts to protect the Sargasso Sea through the SSA and the ssc. ${ }^{46}$

40 See IUCN, Parks Magazine: Special Issue on High Seas Marine Protected Areas, Vol 15, No 3 (KM Gjerde and G Kelleher, eds. 2005), https://www.iucn.org/sites/dev/files/import/ downloads/15_3_lowres.pdf.

41 IUCN, 'Sylvia Earle and IUCN Invite World Leaders to Celebrate and Extend Ocean Protection' (5 October 2009), https://www.iucn.org/content/sylvia-earle-and-iucn -invite-world-leaders-celebrate-and-extend-ocean-protection\#.

The ssA was initially chaired by Dr Frederick W Ming, Director of Bermuda's Department of Environmental Protection, with support from Dr Sheila McKenna and others in the Bermuda government. David Freestone also attended this meeting.

43 Laffoley, Roe et al., above (n 16), 6.

44 The TED/Mission Blue Cruise was a contribution to fulfilling Dr Sylvia Earle's wish at TED Conference 2009 to do all she could to create a network of MPAs. See Sylvia Earle, 'My Wish: Protect Our Oceans' TED (February 2009), https://www.ted.com/talks/sylvia_earle_ s_ted_prize_wish_to_protect_our_oceans; see also K Gjerde, 'Mission Blue Voyage: Making Law on the High Seas', TED (2010), https://www.ted.com/talks/kristina_gjerde_making_ law_on_the_high_seas.

45 David Shaw became the first chair of the ssa Executive Committee and produced an excellent short film entitled the 'Sargasso Sea Tribute \& Declaration' for the signing of the Hamilton Declaration establishing the ssc. The film was shown at the 2015 Ocean Conference and is available at https://vimeo.com/89868953.

46 See ssc, 'In Memoriam—Richard Rockefeller' (2014), http://sargasso.nonprofitsoapbox. com/highlights/157-in-memoriam-richard-rockefeller-\#. 
The original objectives of the Sargasso Sea Alliance were (1) to build an international partnership that will secure recognition of the ecological significance of the Sargasso Sea and the threats that it faces, (2) to use existing regional, sectoral, and international organizations to secure a range of protective measures for all or parts of the Sargasso Sea to address key threats, and (3) to use the process as an example of what can and cannot be delivered through existing institutions with competence in ABNJ. ${ }^{47}$

From 2010 to 2014, the Alliance under Freestone mobilized support from a wide variety of national and international organizations and governments to seek legal protection for this critical ecosystem. ${ }^{48}$ The first step was to build the science foundation. This need to consolidate the science led to the production of the Summary Science and Supporting Evidence Case, which was spearheaded by Professors Laffoley and Howard Roe with input from seventy-four collaborators from over ten countries and eleven institutions. ${ }^{49}$ Completed and approved by the Bermuda Cabinet and the United Kingdom Government, the Summary Science and Supporting Evidence Case was complemented by a large number of topic-specific reports all published in $2011 .{ }^{50}$ This scientific legwork was critical in securing recognition of the Sargasso Sea as an EBSA in 2012. This was followed by recognition by the United Nations General Assembly (UNGA) of the efforts of the sSA, based on a proposal by the United Kingdom, the United States, and South Africa in 2012. ${ }^{51}$ At the same

47 For the ssa objectives, see ssc, 'Sargasso Sea Alliance', http://sargasso.nonprofitsoapbox. com/about-the-alliance/organizational-structure.

48 Key partners at the time included Mission Blue/the Sylvia Earle Alliance, IUCN and its World Commission on Protected Areas, National Oceanic and Atmospheric Administration (NOAA), Stanford University's Center for Ocean Solutions, the Marine Conservation Biology Institute, and the World Wildlife Fund (WWF). There are now 32 Collaborating Partners and three Programmatic Partners. See ssc, 'About the Commission', http://www. sargassoseacommission.org/about-the-commission/collaborating-partners.

49 Laffoley, Roe et al., above (n 16$)$.

$5^{\circ}$ The science series is available at the SSC website, including links to downloadable PDF s of related papers commissioned by thessa, 'Publications and News:ssa Science ReportSeries', http://www.sargassoseacommission.org/publications-and-news/sargasso-sea-alliance -science-report-series.

51 The Sargasso Sea reference has continued to be included every year since then. See UNGA, Resolution 67/78: Oceans and the law of the sea, adopted 11 December 2012, para 199 (proposed by the United Kingdom, the United States and South Africa); UNGA, Resolution 68/ 70: Oceans and the law of the sea, adopted 9 December 2013, para 215 (proposed by the United Kingdom, the United States and the Bahamas); UNGA, Resolution 69/245: Oceans and the law of the sea, adopted 29 December 2014, para 231 (proposed by South Africa 
time, the ssa, together with the Government of Bermuda, initiated efforts involving the two relevant regional fisheries management organizations (RFMOs) for the Sargasso Sea: the Northwest Atlantic Fisheries Organization $(\mathrm{NAFO})^{52}$ and the International Commission for the Conservation of Atlantic Tunas (ICCAT). ${ }^{53}$ The commitment of the sSA to ocean conservation was recognized by a SeaKeeper Award to the Executive Committee ${ }^{54}$ of the ssa by the International SeaKeeper Society in 2013.

Despite this progress, Freestone realized it was time to take ssA efforts to the next level to achieve a higher degree of international cooperation and recognition. Two years of at times tense negotiation amongst some fifteen governments and the European Union ${ }^{55}$ culminated in the signing of the

and the Bahamas, supported by the United Kingdom, the United States and Monaco); UNGA, Resolution 70/235: Oceans and the law of the sea, adopted 23 December 2015, para 302 (proposed by South Africa and the Bahamas, supported by the United Kingdom, the United States and Monaco); UNGA, Resolution 71/257: Oceans and the law of the sea, adopted 23 December 2016, para 329 (proposed by the Bahamas, supported by the United Kingdom, the United States and Monaco); UNGA, Resolution 72/73: Oceans and the law of the sea, adopted 5 December 2017, para 342 (proposed by the Bahamas, supported by the United Kingdom, the United States and Monaco). See also ssc, 'Our Work: United Nations General Assembly', http://www.sargassoseacommission.org/about-our-work/ relevant-organizations/united-nations-general-assembly.

52 The 1978 NAFO Convention on Future Multilateral Cooperation in the Northwest Atlantic Fisheries (1135 UNTS 370) applies to most fishery resources of the Northwest Atlantic except salmon, tunas/marlins, whales, and sedentary species (e.g., shellfish). As of 2020, NAFO has twelve members from North America, Europe, Asia, and the Caribbean. Among them are four coastal members bordering the Convention Area: the United States, Canada, France (in respect of St. Pierre et Miquelon), and Denmark (in respect of Faroe Islands and Greenland). See Northwest Atlantic Fisheries Organization (NAFO), 'About Us', https://www.nafo.int/About-us.

53 See Section 6.1.2: International Commission for the Conservation of Atlantic Tunas below.

54 Executive Committee members at the time included Dr Derrick Binns, David Freestone, Kristina Maria Gjerde, Kate Killerlain Morrison, Richard Rockefeller, Howard Roe, and David Evans Shaw. See infra for discussion of the ssA's achievements earning the International SeaKeepers Society's SeaKeeper Award (2013), http://www.seakeepers.org/ award/. For a short video of the 2013 SeaKeeper Award ceremony by David Shaw, see https://vimeo.com/77808189.

55 D Freestone and KK Morrison, "The Signing of the Hamilton Declaration on Collaboration for the Conservation of the Sargasso Sea: A New Paradigm for High Seas Conservation?' (2014) 29 International Journal of Marine and Coastal Law 345-362. The ssA convened two technical meetings at the Pocantico Center of the Rockefeller Brothers Fund comprised of representatives from interested States and international organizations (2-4 December 2012 and 23-24 November 2013); both were led by Freestone and Rockefeller. The draft text of a political declaration was discussed in preparation for approval and signing by an inter-governmental meeting in March 2014 in Hamilton, Bermuda (this became the Hamilton Declaration). 
Hamilton Declaration, which established three new bodies: (1) a Meeting of the Collaborating Government Signatories, (2) the ssc, and (3) an Executive Secretariat to assist the SSC in organizing meetings and carrying out decisions. Freestone was made the Executive Secretary to recognize his work in leading the SSA.

\section{5 The Hamilton Declaration}

On 11 March 2014, representatives of five governments (Bermuda, Monaco, the Azores, the United Kingdom, and the United States) signed the Hamilton Declaration on Collaboration for the Conservation of the Sargasso Sea (Hamilton Declaration) ${ }^{56}$ at a large meeting in Hamilton, Bermuda. Many more governments attended, or expressed interest in attending, but were unable to sign at that time. ${ }^{57}$ Five more governments have signed in the period up to writing. 58

The Hamilton Declaration is the first non-binding instrument establishing an international framework for its Signatory Governments to cooperate to minimize the adverse effects of human activities on an ecosystem that lies primarily beyond national boundaries. ${ }^{59}$ The Signatories affirm that the 'guiding principle of this Declaration is to conserve the Sargasso Sea ecosystem for the benefit of present and future generations'. The Signatories also affirm that they 'decide to collaborate, to the extent possible, in pursuing conservation measures for the Sargasso Sea through existing regional and international organizations with relevant competences' ${ }^{\prime}$ The Declaration mandates the

56 Adopted 11 March 2014, http://www.sargassoseacommission.org/storage/Hamilton Declaration_with_signatures_April_2018.pdf.

57 Besides the five Signatories, other governments attending included representatives from the Bahamas, the British Virgin Islands, the Netherlands, South Africa, Sweden, and the Turks and Caicos Islands, together with observers from the secretariats of five international organizations, the Oslo and Paris Commission (OSPAR) from the neighbouring North East Atlantic region, the International Seabed Authority, the Inter-American Convention for the Protection and Conservation of Sea Turtles, the Convention on Migratory Species, and the IUCN. See Freestone and Morrison, above (n 55), 345-346.

58 The five additional Signatories are the British Virgin Isles (29 January 2016), the Bahamas (27 September 2016), Canada (3 December 2016), the Cayman Islands (3 January 2017), and the Dominican Republic (6 April 2018). See ssc, 'News', http://www.sargassoseacommission.org/publications-and-news.

59 For details about the Declaration as an innovative model for voluntary governance in the ABNJ (the foundation for this essay), see Freestone and Bulger, above (n 10), 80-9o. Ibid. 
establishment of the ssc, an independent science-based body comprised of 'distinguished scientists and other persons of international repute' to act as the 'Steward' of this unique ecosystem. ${ }^{61}$

Another innovative element of the Hamilton Declaration is that nongovernmental entities interested in contributing to the conservation of the Sargasso Sea could be invited to join as Collaborating Partners. Collaborating Partners currently include: Duke Marine Geospatial Ecology Laboratory; Institute for Advanced Sustainability Studies (Germany); International Cable Protection Committee (ICPC); IUCN, IUCN WC PA; Marine\& Environmental Law Institute, Dalhousie University (Canada); Nekton/Code Blue Foundation, Sea Education Association, the Humpback Whale Project (Bermuda); Institute for Sustainable Development and International Relations (France), International SeaKeepers Society; The Maine and Environmental Sciences Centre (Portugal); Mission Blue/Sylvia Earle Alliance; Plymouth Marine Laboratory (United Kingdom); University of Central Florida Marine Turtle Research Group; and wWF International. ${ }^{62}$

As part of its stewardship role, the SsC is charged with developing a work programme and action plan in consultation with the Signatories. ${ }^{63}$ The Signatories then have the opportunity, jointly or individually, to submit agreedupon proposals for protection measures to the appropriate international bodies with legal authority or competence over relevant activities.

At the First Joint Meeting in October 2014, the SSC and Signatories built on the original aims of the SSA to embrace the following overarching goals: (1)

61 While the ssc has no legal competence or authority of its own, it is charged with 'exercis[ing] a stewardship role for the Sargasso Sea and keep[ing] the Sea's health, productivity and resilience under continual review'. Hamilton Declaration, above ( $\left.\mathrm{n}_{56} 6\right)$.

62 See ssc, 'About the Commission', http://www.sargassoseacommission.org/about-thecommission/collaborating-partners.

63 Ibid. On the appointment procedure, see ssc, Rules of Procedure, adopted 21 October 2014, Doc Mos/ssc/2014/1/App.I/Ann.I, http://www.sargassoseacommission.org/ storage/documents/MOS_SSC_2014_1_App.I_Ann.I.pdf. To ensure circulation of the Commission membership, the first five Commissioners were appointed to staggered terms in 2014. Professor Dire Tladi (South Africa) was given a one-year term, Professor Howard Roe (United States) and Dr Billy Causey (United States) were given two-year terms, and Professor Ricardo Serrão Santos (Azores) and Dr Tammy Trott (Bermuda) were given three-year terms. In 2015, Professor Dire Tladi stepped down and Professor Stephen De Mora and Mr Mark Spalding were newly appointed, raising the number of Commissioners to six. In 2016, Professor Roe and Dr Causey were reappointed. In 2017, Professor Santos retired and Mr Federico Cardigos (Azores) was newly appointed, Senator (retired) Wilfred Moore (Canada) was newly appointed, and Dr Tammy Warren was reappointed. This raised the number of Commissioners to seven. In 2018, Professor De Mora and Mr. Spalding were re-appointed. 
promote international recognition of the unique ecological and biological nature and global significance of the Sargasso Sea; (2) encourage scientific research to expand existing knowledge of the Sargasso Sea ecosystem in order to further assess its health, productivity, and resilience; and (3) develop proposals for submission to existing regional, sectoral, and international organizations to promote the objectives of the Hamilton Declaration. ${ }^{64}$ The First Joint Meeting also adopted the First Biennial (2015-2017) Work Programme of goals and priority activities. ${ }^{65}$ The Second Biennial (2016-2018) Work Programme was developed at the Second Joint Meeting of the Signatories and the SsC, which was held in Key West, Florida, in March 2016.66 The Third Joint Meeting of Signatories and the SSC was held in Horta, Azores in April 2017 hosted by the Government of the Azores, which once again updated the Work Plan. ${ }^{67}$ The Fourth Joint Meeting of the Signatories and ScC was convened at the Bermuda Institute for Ocean Sciences, St George's, Bermuda, March 2019, and was preceded by an experts workshop to consider whether and how the Sargasso Sea initiative might evolve into a more formal regional agreement or a form of regional ocean governance organization (ROGO) that would be governed by a treaty that is binding under international law. ${ }^{68}$

The sections directly below detail the activities of the SSA and the SSC and Signatories under Freestone's leadership to advance the conservation of the Sargasso Sea. As will be seen, the intergovernmental and other bodies that have been engaged bodies include the NAFO and ICCAT (fishing sector), International Maritime Organization (IMO) (shipping sector), the ICPC (cable-laying sector), the Secretariat for the Convention on the Conservation of Migratory Species of Wild Animals (CMS), the US National Aeronautics and Space Administration (NASA), the UN Environment Programme, the

64 ssc, 'About the Commission', http://www.sargassoseacommission.org/about-our-work.

65 ssc, Work Programme Priorities (2015-2017), Doc ssc/2014/1/Doc.1, http://www.sargassoseacommission.org/storage/documents/SSC_2014_1_Doc.1.pdf.

66 Ssc, Work Programme Priorities (2016-2018), Doc ssc/2016/2/Doc.1, http://www.sargassoseacommission.org/storage/documents/MOS_SSC_2016_2_Doc.1_Work_Programme_ 2016-2018_revised_1.pdf.

67 The work programmes and stewardship plan are on the Sargasso Sea Commission website, above (n 67).

68 Personal communication with Ole Varmer, 5 March 2019. See also presentation by Freestone at 13 March 2019 Workshop and Fourth Joint Meeting of the Sargasso Sea Commission and Hamilton Declaration Signatories in Bermuda, 'The Sargasso Sea Commission: The Story So Far ..., http://www.sargassoseacommission.org/storage/documents/Freestone_The_story_so_far_Bermuda_March_13_2019.pdf. 
Intergovernmental Oceanographic Commission and the International Seabed Authority (ISA) (mining sector). ${ }^{69}$

\subsection{Habitat Conservation in Fisheries Organizations - Fisheries Sectors}

NAFO and ICCAT are the two RFMOs with regulatory competence in areas of the Sargasso Sea. NAFO is responsible for non-tuna species within its quadrant of the Northwest Atlantic, while ICCAT is responsible for tuna and tuna-like species throughout the Atlantic Ocean..$^{70}$ The Sargasso Sea team's long-term efforts at ICCAT is detailed below to illustrate the difficulties in securing application of an ecosystem approach to fisheries management and the precautionary approach to habitat conservation in the Sargasso Sea. The experience with NAFO illustrates the challenges of securing long-term protection of habitats that have been recognized as both significant and vulnerable. Temporary protection is insufficient to protect long-lived, fragile and slow to recover species found on most seamounts. It is also important to note that there remains a large area of the Sargasso Sea not covered by an RFMo for non-tuna species, but covered instead by the Western Central Atlantic Fishery Commission (WECAFC), ${ }^{71}$ an advisory body sponsored by the Food and Agriculture Organization of the

69 See ssc, 'Work Programme', http://www.sargassoseacommission.org/about-our-work.

70 The ICCAT Convention area covers the entire Atlantic Ocean, including the Sargasso Sea Alliance Study Area, however, its authority is limited to management of tuna and tuna-like species. About 30 species are of direct concern to ICCAT, including Atlantic bluefin (Thunnus thynnus thynnus), skipjack (Katsuwonus pelamis), yellowfin (Thunnus albacares), albacore (Thunnus alalunga) and bigeye tuna (Thunnus obesus); swordfish (Xiphias gladius); billfishes such as white marlin (Tetrapturus albidus), blue marlin (Makaira nigricans), sailfish (Istiophorus albicans) and spearfish (Tetrapturus pfluegeri); mackerels such as spotted Spanish mackerel (Scomberomorus maculatus) and king mackerel (Scomberomorus cavalla); and small tunas like black skipjack (Euthynnus alletteratus), frigate tuna (Auxis thazard), and Atlantic bonito (Sarda sarda). See ssc, 'About Our Work: International Commission for Conservation of Atlantic Tunas (ICCAT)', http:// www.sargassoseacommission.org/about-our-work/relevant-organizations/internationalcommission-for-the-conservation-of-atlantic-tuna. See also ICCAT, Resolution 12-12 on the Sargasso Sea, transmitted to Contracting Parties 28 November 2012, paras 1-2.

71 The WECAFC's central mission is 'to promote the effective conservation, management and development of the living marine resources of the area of competence of the Commission, in accordance with the FAO Code of Conduct for Responsible Fisheries, and address common problems of fisheries management and development faced by members of the Commission. As part of this mission, the WECAFC contributes to and coordinates with other institutions and international organizations on issues of public interest, including taking an ecosystem approach to fisheries management. FAO Fisheries and Agriculture Department, 'Regional Fishery Bodies Summary Descriptions: Western Central Atlantic Fishery Commission (WECAFC)', http://www.fao.org/fishery/rfb/wecafc/ en. 
United Nations (FAO). WECAFC is focused on promoting collaboration on nontuna fisheries in the national waters and high seas stretching from the southern border of NAFO that crosses Bermuda's EEZ south to Brazil and out to the mid-Atlantic. ${ }^{72}$ If WECAFC were to be transformed into an RFMO, as some are proposing, ${ }^{73}$ it would have a much larger role in the Sargasso Sea. However, as of yet, most non-tuna fisheries in the Sargasso Sea remain unregulated.

\subsubsection{Northwest Atlantic Fisheries Organization}

One of the major accomplishments of the SSA/SSC initiative is the NAFO closure in 2017 of several seamounts to deep sea bottom fishing through 2020 including restrictions on the use of certain types of midwater trawling gear in the area near those seamounts. ${ }^{74}$ As noted by Diz, " $[\mathrm{t}]$ his is an important development in international environmental law and the law of the sea, as it brings together two biodiversity concepts, namely the FAO's vulnerable marine ecosystems (VMEs) and the [CBD]'s [EBSAs].75

In addition, the NAFO Scientific Council has developed single stock assessments and has identified benthic areas of concern, including VMEs and seamounts for other bottom fishing closures. Our understanding is that the Council is currently working to provide ecosystem summary sheets to managers on what is happening in the food web, climate change, and ocean

72 With regard to WECAFC species and stock coverage: 'All living marine resources, without prejudice to the management responsibilities and authority of other competent fisheries and other living marine resources management organizations or arrangements in the area'. Ibid. As such, the WECAFC focuses on all fish stocks in the otherwise-uncovered portion of the Sargasso Sea, as opposed to promoting one or two species.

73 WECAFC, Summary report of the First preparatory meeting of the Western Central Atlantic Fishery Commission (WECAFC) for the transformation into a Regional Fisheries Management Organization, Doc WECAFC/SAG/X/2019/2 (4 June 2019), http://www.fao. org/fi/static-media/MeetingDocuments/WECAFC/SAG2019/2.pdf.

74 NAFO's 37th Annual Meeting in Halifax in September 2015 agreed to (1) prohibit the use of attachments of mid-water trawling gear that could damage or touch the seabed, and require all vulnerable marine ecosystem indicator species caught during mid-water trawling be reported; and (2) close completely all seamounts in the NAFO area to bottom trawling activities until the end of 2020 by prohibiting bottom trawling exemptions for exploratory fishing. See ssc, 'NAFO Agrees to Significant Protections for Sargasso Seamounts', Publications and News, http://www.sargassoseacommission.org/publications-and-news/ news.

75 D Diz, 'The Sargasso Sea' (2016) 31 International Journal of Marine and Coastal Law 359-370. 
conditions including in the overlap areas between the NAFO Convention Area and the Sargasso Sea. ${ }^{76}$

However, despite this success, the temporary, case-by-case approach reflected in the 2017 NAFO resolution suggests that it may be time to consider a permanent ban on bottom trawling to protect biodiversity on all seamounts themselves. ${ }^{77}$ The need to improve the management of deep sea bottom fishing to protect deep sea biodiversity had been globally recognized since 2006 via a UNGA resolution calling for States and RFMOs to manage deep sea bottom fisheries to prevent significant adverse impacts on vulnerable marine ecosystems like seamounts and deep sea corals. ${ }^{78}$ While NAFO agreed to a legally binding closure in 2017, this is a temporary closure that will expire in 2020. A permanent ban ${ }^{79}$ could better ensure the conservation of biodiversity and preservation of a healthy habitat and ecosystem, ${ }^{80}$ which will yield long-term benefits not only to the global economy, but also to the fisheries industry itself as a cornerstone for ecosystem-based management.

\subsubsection{International Commission for the Conservation of Atlantic Tunas}

The first-ever action by ICCAT to consider habitat and ecosystem concerns was sparked by a resolution submitted by the United States (US) delegation at ICCAT's 2005 meeting in Seville, Spain. The resolution was to protect pelagic

76 See M Koen-Alonso, P Pepin, MJ Fogarty et al., 'The Northwest Atlantic Fisheries Organization Roadmap for the Development and Implementation of an Ecosystem Approach to Fisheries: Structure, State of Development, and Challenges' (2019) 100 Marine Policy 342-352.

77 See further, L Watling and PJ Auster, 'Seamounts on the High Seas Should Be Managed as Vulnerable Marine Ecosystems' Frontiers in Marine Science (25 January 2017), https://doi. org/10.3389/fmars.2017.00014.

78 See UNGA, Resolution 61/105: Sustainable fisheries, adopted 8 December 2006, paras 8083; UNGA, Resolution 66/68: Sustainable fisheries, adopted 6 December 2011, para 121.

79 For example, in 2013, Chile legislated a permanent ban on bottom trawling on seamounts. A Muñoz, 'Chile Becomes First Country to Protect All Seamounts from Bottom Trawling', National Geographic blog (14 January 2013), https://blog.nationalgeographic.org/2013/o1/ 14/chile-becomes-first-country-to-protect-all-seamounts-from-bottom-trawling/. In relation to EU waters, Article 8(4) of Regulation (EU) 2016/23361 prohibits the use of bottom trawl gear below 800 metres, while Article 9 restricts fishing in vMEs. Regulation (EU) 2016/2336 of the European Parliament and of the Council of 14 December 2016 establishing specific conditions for fishing for deep-sea stocks in the north-east Atlantic and provisions for fishing in international waters of the north-east Atlantic and repealing Council Regulation (EC) No 2347/2002, OJ L 354 (23 December 2016).

80 See, for example, F Althaus, A Williams, TA Schlacher et al., 'Impacts of Bottom Trawling on Deep-coral Ecosystems of Seamounts Are Long-lasting' (2009) 397 Marine Ecology Progress Series 279-294. 
Sargassum as essential fish habitat for highly migratory species. The United States was acting pursuant to a request made by the US's South Atlantic Fishery Management Council (SAFMC) to the National Marine Fisheries Service (NMFS) of National Oceanic and Atmospheric Administration (NOAA) to consider protection of Sargassum habitat in ABNJ. This US resolution followed the SAFMC's development of the Fishery Management Plan for Pelagic Sargassum Habitat of the South Atlantic Region to protect the US EEZ from large scale harvest. ${ }^{81}$ Unfortunately there was never any follow up to this resolution and no parties supplied any further scientific information, not even the United States.

The Sargasso Sea team initiated its contacts with ICCAT by holding a side event at a meeting of the Standing Committee on Research and Statistics (SCRS) SubCommittee on Ecosystems in 2010 in Miami, and it continues to attend those sub-committee meetings as well as the full sCRS and the Commission. In 2011, the Government of Bermuda formally introduced the Alliance objectives through an intervention at the meeting of the ICCAT Commission. At the July 2012 InterSessional Meeting of the Sub-Committee on Ecosystems in Sète, France, the SubCommittee encouraged the SSA representative to submit to the Sub-Committee a SCRS document or similar report with more detailed information on the initiative, and at the 2012 ICCAT Commission meeting (November 2012, Agadir, Morocco), the ICCAT Commission agreed by Resolution 12-12 that:

1. The SCRS will examine the available data and information concerning the Sargasso Sea and its ecological importance to tuna and tuna-like species and ecologically associated species.

2. The SCRS will provide an update on the progress of this work in 2014 and report back to the Commission with its findings in 2015 .

Drs Tammy Trott and Brian Luckhurst participated in the July 2013 ICCAT Ecosystems Subcommittee meeting, on behalf of Bermuda, as members of the UK Overseas Territories delegation. Dr Luckhurst's inventory reports and

81 South Atlantic Fishery Management Council (SAFMc), Second Revised Final Fishery Management Plan for Pelagic Sargassum Habitat of the South Atlantic Region (NOAA, 2002) (including an FEIS), https://www.gc.noaa.gov/documents/gcil_safmc_fmp.pdf. In 2003, NOAA issued a Rule to Implement Fishery Management Plan for Pelagic Sargassum Habitat of the South Atlantic Region: 68 Fed. Reg. 57375 (3 October 2003). The SAFMC has also requested NOAA consider protection of the Sargassum habitat in the ABNJ. See Letter dated 8 September 2005 from Dr Louis Daniel III, Chair of the SAFMC to the Asst Admin of NMFS NOAA, http://cdn1.safmc.net/wp-content/uploads/2016/11/28110159/ Sargassumltr_Daniel.pdf. 
presentation on the significance of the Sargasso Sea for tuna and tuna-like species were well received. ${ }^{82}$ The ICCAT Ecosystem Subcommittee report states:

The Group recommends continuing the contact with Sargasso Sea research teams and the UK-Bermuda scientists to develop a scientific collaborative plan to accomplish objective 2 of Res [12-12]. Additionally, the Group recognized that the above work is providing a useful foundation for adopting this region as a basis for a case study in implementing the Ecosystem Based Fisheries Management (EBFM) approach within ICCAT and this collaboration should continue to be supported. ${ }^{83}$

The same team participated as members of the UKOT delegation at the ICCAT Ecosystems Subcommittee (Portugal, September 2014). The Subcommittee received two scientific papers prepared by Dr Luckhurst, 'Analysis of ICCAT Reported Catches of Tunas and Swordfish in the Sargasso Sea (1992-2011), ${ }^{\prime 4}$ as well as 'A Preliminary Food Web of the Pelagic Environment of the Sargasso Sea with a Focus on the Fish Species of Interest to ICCAT'85 These studies were commissioned by the Sargasso Sea Project.

At the June 2015 meeting of the ICCAT's Ecosystem Subcommittee in Madrid, Dr Luckhurst presented his paper on the spawning areas in the Southern Sargasso Sea for swordfish, albacore tuna and white marlin. ${ }^{86}$ The Subcommittee considered proposals on how to protect the habitat of these commercially important fish species and recommended that (1) work continue in order to further our understanding of the Sargasso Sea ecosystem, (2) consideration be given to using the Sargasso Sea ecosystem as a model for demonstrating the implementation of an ecosystem-based fisheries management framework, and (3) mechanisms be found to improve communication among groups to share and transfer new knowledge and tools emerging from all the

82 BE Luckhurst, Inventory and Ecology of Fish Species of Interest to ICCAT in the Sargasso Sea, ICCAT Doc SCRS/ 2013/132.

83 See ICCAT, 2013 Inter-sessional Meeting of the Sub-Committee on Ecosystems, Madrid, Spain, 1-5July 2013, http://www.sargassoseacommission.org/storage/documents/2013_SCECO_REPORT_ENG.pdf, Part I: Ecosystem, 6.

84 ICCAT, Doc SCRS/2O14/119.

85 ICCAT, Doc SCRS/2014/120.

86 BE Luckhurst and F Arocha, Evidence of Spawning in the Southern Sargasso Sea of Fish Species Managed by ICCAT: Albacore Tuna, Swordfish and White Marlin, ICCAT Doc SCRS2O15/111. 
ICCAT working groups as the number of ecosystem-related research activities had increased. ${ }^{87}$

To follow up on this recommendation, Bermuda, on behalf of the ssc, put forward a draft resolution in 2016 to recognize the importance of the Sargasso Sea for a number of ICCAT species and for its suitability as a possible pilot area for an ecosystem-based approach to fisheries management. Japan instead proposed an amendment to recognize that a number of ecosystems were of importance to ICCAT species in the Convention area, apparently seeking to prevent formal recognition of the Sargasso Sea. The result was Resolution 1623 , which contained all the preambular wording of the Bermuda proposal, but resolved:

1. As part of advancing the work of Ecosystem Based Fisheries Management, the SCRS will examine the available information on the trophic ecology of pelagic ecosystems that are important and unique for ICCAT species in the Convention Area.

2. The SCRS will provide an update on the progress of this work in 2018 and report back to the Commission with available findings in 2019, if possible. ${ }^{88}$

To address this challenge, the ssc commissioned a paper from Dr Laurie Kell (formerly of the ICCAT Secretariat) and Dr Luckhurst on 'Extending the Indicator-Based Ecosystem Report Card to the Whole Ecosystem; A Preliminary Example Based on the Sargasso Sea. 89 The paper, presented in 2018, utilizes a report card approach adopted by the Sub-Committee in 2017.90 The Sub-Committee agreed to further develop the concepts presented in the paper, and at its 2019 meeting the same authors presented a more developed paper, 'Extending the Indicator-Based Ecosystem Report Card to the Whole Ecosystem; A Preliminary Example Based on the Sargasso Sea.' ${ }^{91}$

87 ICCAT, 2015 Inter-sessional meeting of the Sub-Committee on Ecosystems, Madrid, Spain, 812 June 2015, http://www.sargassoseacommission.org/storage/documents/2015_SCECO_ REPORT_ENG.pdf; see also Luckhurst and Arocha, above (n 86).

88 ICCAT, Resolution 16-23 on ecosystems that are important and unique for ICCAT species, transmitted to Contracting Parties 12 December 2016.

89 Ssc, 'ICCAT Ecosystems Sub-Committee' Sargasso Sea Commission Newsletter (World Oceans Day 2018), http://myemail.constantcontact.com/World-Oceans-Day-SargassoSea-Commission-Newsletter.html?soid=1109154724045\&aid=hupfna_2Wfg.

90 The paper was presented at the June 2018 Madrid meeting of the ICCAT Ecosystems SubCommittee. MJ Juan-Jordá, H Murua, H Arrizabalaga and A Hanke, 'A Template for an Indicator-Based Ecosystem Report Card for ICCAT' (2018) 74 Collective Volume of Scientific Papers ICCAT 3639-3670.

91 ICCAT Doc SCRS/2018/067, reproduced in (2018) 75(2) Collective Volume of Scientific Papers ICCAT 258-275. 
The long history of these efforts at ICCAT illustrates the challenges in seeking application of an ecosystem approach to habitat conservation in the Sargasso Sea. Despite a tremendous wealth of scientific information on the importance of conserving Sargasso Sea biodiversity, the need for more science is always put forward to block even precautionary measures, despite calls for a precautionary approach in the UN Fish Stocks Agreement, the FAO Code of Conduct for Responsible Fisheries and many other soft law declarations. ${ }^{92}$ Satellite surveillance from automatic identification system records now demonstrates increased fishing activity in the Sargasso Sea, and marked increases in shipping frequency, primarily in the southern part. ${ }^{93}$ Thus an important opportunity to control fisheries expansion into the Sargasso Sea consistent with an ecosystem approach may well have been lost.

The inability of the ICCAT to act, particularly the apparent unwillingness of some of its members to apply a precautionary approach or even to adopt the SCRS recommendations, should be considered in the UN negotiating process as one of the many reasons that fisheries should not be exempt from the legally binding agreement for the conservation of ABNJ. Rather, the example of ICCAT suggests that the UN process offers an important opportunity to accelerate RFMO progress by incorporating obligations to implement both the precautionary principle and the ecosystem-based approach in all sectoral activities, and by enhancing institutional accountability, transparency, and responsiveness to public interests in truly sustainable management that incorporates broader ecosystem-concerns. ${ }^{94}$ In the case of fisheries, such concerns include broader habitat, non-target species, and trophic level effects. ${ }^{95}$

92 Freestone, Modern Principles, above (n 9), 46.

93 See P Woods, 'Global Fishing Watch' presentation to Sargasso Sea Commission, 13 March 2019, http://www.sargassoseacommission.org/storage/GFW_-_Sargasso_Sea_ Commission_March_2019_2_1.pdf.

94 Freestone and Gjerde, Lessons, above (n 11); see also R Barnes, 'The Proposed LOSC Implementation Agreement on Areas beyond National Jurisdiction and its Impact on International Fisheries Law' (2016) 31 International Journal of Marine and Coastal Law 583-619.

95 ICCAT is not alone in its reluctance to address habitat and trophic level concerns. A recent review of tuna RFMOs notes that '[a]ll RFMOs share the same challenge of developing a formal mechanism to better integrate ecosystem science and advice into management decisions'. MJ Juan-Jordá, H Murua, H Arrizabalaga et al., 'Report Card on Ecosystembased Fisheries Management in Tuna Regional Fisheries Management Organizations' (2017) 19(2) Fish and Fisheries 321-339. 


\subsection{International Maritime Organization - the International Shipping Sector}

Early hopes for swift progress at the IMO in reducing the impacts of shipping in the Sargasso Sea turned out to be overly optimistic due to demands by some key States for proof of harm as opposed to extrapolations from similar ecosystems that harm was likely. ${ }^{96}$ In 2011 , the sSA published a major report on the threats posed to the Sargasso Sea by international shipping. ${ }^{97}$ It identified vessel traffic characteristics (i.e., operational factors, vessel types, and harmful substances carried), provided a comprehensive spatial analysis of international shipping movements in the North Atlantic and assessed potential effects from such activities. The report suggested that future efforts focus on the risks posed by the disposal of garbage, sewage and other wastewaters, including ballast water discharge. It also suggested that the physical impacts of shipping on marine flora and fauna, most notably noise and ship-strikes, may be worth further consideration. The ssA organized three side events at the IMO to raise awareness about the Sargasso Sea.

The initial focus for possible IMO protective measures was identification of the Sargasso Sea as a Particularly Sensitive Sea Area (PSSA) as a tool to raise mariners' attention - a concept Freestone and Gjerde helped to develop during the 199os through various initiatives, including workshops with the I M O. ${ }^{98}$ Other possible measures included designation of the Northern Atlantic Subtropical Gyre that surrounds the Sargasso Sea as a MARPOL Special Area to restrict and limit the accumulation of operational discharges of garbage, oil, hazardous substances, sewage, and air emissions of sulphur dioxide. ${ }^{99}$ Ship routeing measures such as traffic separation schemes, precautionary areas, areas to be avoided, as well reporting systems could also be relevant minimize noise and risks of ship strikes.

The challenge however of progressing protective measures via the IMo has been the burden of proof issue in a remote and understudied area. Although the IMO PSSA Guidelines say that it is 'helpful' to have 'any evidence that international shipping activities are causing damage and whether damage is

96 See also, Freestone and Gjerde, Lessons, above (n 11).

97 J Roberts, Maritime Traffic in the Sargasso Sea: An Analysis of International Shipping Activities and their Potential Environmental Impacts, Report to IUCN/Sargasso Sea Alliance Legal Working Group by Coastal \& Ocean Management, Hampshire, UK. Sargasso Sea Alliance Science Report Series No 9 (2011).

98 See KM Gjerde and D Freestone (eds), Special Issue: 'Particularly Sensitive Sea Areas: An Important Environmental Concept at a Turning Point?' (1994) 9(4) International Journal of Marine and Coastal Law 431-579.

See Roberts, above (n 99). 
of a recurring or cumulative nature, ${ }^{100}$ what the SSA experienced in practice was far different: many influential delegations at IMO take these Guidelines to be an evidentiary requirement. ${ }^{101}$ Freestone and Harris observe that as a result of this evidentiary standard, there are no PSSAs in ABNJ, nor have IMO members taken advantage of other IMO instruments, especially MARPOL, in attempting to conserve biodiversity in the high seas that might be impacted by international shipping. ${ }^{102}$ The BBNJ process might offer an important opportunity to address the issues identified by the SSA and SsC and formally adopt the precautionary principle/approach and the ecosystem approach into the IMO and other sectoral decision-making practices and make these approaches operational. ${ }^{103}$

\subsection{International Seabed Authority - the Mining Sector}

In 2011, the SSA commissioned a study of the geology of the Sargasso Sea. ${ }^{104}$ The report also provided an overview of the potential occurrence of non-living marine resources and interested international organizations. The resources identified that could be of long-term potential commercial interest included polymetallic sulphides and gas hydrates, though no significant deposits were noted.

As regulation of seabed mining in the international seabed 'Area' including the Sargasso Sea is under the competence of the ISA, a representative from the ISA was invited to participate as an observer at the Hamilton meeting in March 2014. The SSC was granted observer status at the ISA in the summer of 2015. A representative of the ssc has been attending most ISA meetings since then

100 Ibid; seeJ Roberts, Marine Environmental Protection and Biodiversity Conservation (Elsevier, 2007) 150-159; see also S Prior, A Chircop and J Roberts, 'Area based Management of the High Seas: Possible Application of the IMO's Particularly Sensitive Sea Area Concept' (2010) 25(4) International Journal of Marine and Coastal Law 483-522.

101 Freestone and Gjerde, Lessons, above (n 11).

102 See D Freestone and V Harris, 'Particularly Sensitive Sea Areas beyond National Jurisdiction: Time to Chart a New Course?' in M Nordquist, JN Moore and R Long (eds), International Marine Economy: Law and Policy (Brill, 2017) 322-362.

103 Nevertheless, see Strategic Direction 4 in relation to ocean governance in the IMO Strategic Plan 2019-2023, which aims to ensure the sustainable development of activities in the marine space, such activities have to be balanced with the capacity of the oceans to remain healthy and diverse in the long term. IMO, Strategic Plan for the Organization for the Six-year Period 2018 to 2023, Imo Doc A 30/Res.1110 (8 December 2017), Annex, 7.

104 L Parson and R Edwards, The Geology of the Sargasso Sea Alliance Study Area, Potential Non-Living Marine Resources and an Overview of the Current Territorial Claims and Coastal States Interests, Sargasso Sea Alliance Science Report Series No 8 (Sargasso Sea Alliance, 2011). 
and the SsC is taking an active role in the development of what is hoped will be a precautionary and environmentally robust regulatory regime for future mineral exploitation in the Area. ${ }^{105}$

Seabed mining was initially not a concern to the sSA. Under the LOSC, ISA is empowered by Parties to regulate mineral exploration and exploitation on behalf of humankind as a whole. Under LOSC Articles 136-140, the Area and its resources (defined as mineral resources) are designated as the 'Common Heritage of Mankind', to be managed for the benefit of humankind. The ISA under LosC Article 145 is to adopt measures necessary to ensure effective protection of the marine environment from harmful effects which may arise from such activities. Thus, the interests of non-deep seabed mining States and the marine environment are theoretically well protected. The SsC was taken by surprise when the ISA approved in 2017 a fifteen-year exploratory contract for minerals in an area of the mid-Atlantic Ridge that is directly adjacent via prevailing currents to the Sargasso Sea. ${ }^{106}$ Not only was the status of the mid-Atlantic ridge as an $\mathrm{EBSA}^{107}$ not acknowledged, parts of the mid-Atlantic Ridge, like the Sargasso Sea, have been described as an area of outstanding evolutionary, ecological, and scientific significance that could likely meet the criteria for World Heritage sites were the World Heritage Convention applicable to ABNJ. ${ }^{108}$ At present there is no requirement for the ISA to consult with

105 See International Seabed Authority, 'Observers', https://www.isa.org.jm/observers (NGO s are listed in the right-hand column).

106 IISD, 'Summary of the Twenty-fourth Annual Session of the International Seabed Authority (Second Part): 16-26 July 2018', Earth Negotiations Bulletin, http://enb.iisd.org/ oceans/isa/2018-2/. Among the final outcomes of the 24th Council Session (ISBA/24/C/ 22), the Council once again 'encouraged the [Legal and Technical Commission] to hold more open meetings to allow for greater transparency'.

107 While СвD сор Decision X/29: Marine and coastal biodiversity (2010), paragraph 26, emphasizes that that the identification of EBSAs and the selection of conservation and management measures is a matter for States and competent intergovernmental organizations, in accordance with international law, paragraph 32 also encourages Parties, other governments and competent intergovernmental organizations to cooperate, as appropriate, collectively or on a regional or sub-regional basis, to identify and adopt, according to their competence, appropriate measures for conservation and sustainable use in relation to EBSAs, and in accordance with international law, including the LOSC, including by establishing representative networks of MPAs in accordance with international law, including the LOSC, and based on best scientific information available, and to inform the relevant processes within the UNGA.

108 Freestone et al., above (n 28). This report, while recognizing that the 1972 World Heritage Convention (1037 UNTS 151) does not currently extend to ABNJ, identified both the Sargasso Sea and the Lost City on the mid-Atlantic Ridge as two of the five exceptional sites that might be likely to meet the criteria of 'outstanding universal value' required by the Convention for inscription on the list of World Heritage 
those whose interests (whether conservation, scientific or commercial) may be affected prior to approval of an exploration contract. It became even more important for the SsC to become involved in the development of the regulations to govern exploitation contracts.

The continued reluctance or inability of the ISA's Legal and Technical Commission to consult, hold open meetings, or adopt measures to protect vulnerable marine ecosystems from potentially significant effects of exploration, test mining or future exploitation deserves that attention of the UNGA and consideration during the development of the вBNJ instrument. At a minimum, this reluctance underscores the need for the international community to raise expectations of transparency and inclusiveness in sectoral decisionmaking processes and accountability to the global community as a whole. New frontiers in mining the seabed demands rigorous oversight and accountability mechanisms, which are clearly absent in relation to the granting of exploration contracts that may adversely affect Sargasso Sea conservation values.

Improved oversight and accountability could be advanced through the в В NJ agreement for example, by elaborating the duty to cooperate to promote good governance principles both directly and through competent international organizations, through a global process for reviewing progress such as through a global conference of parties, and a coordinated approach to scientific research such as the UN Decade of Science could provide. ${ }^{109}$ The ssc's experience with the ISA also highlights the need for a mechanism to secure comprehensive protection of scientifically valuable and ecologically and biologically significant areas, like the Sargasso Sea, at the global level, with linkages to the sectoral level to ensure that global conservation values and designations are respected.

\subsection{International Cable Protection Committee - Submarine Cable Sector}

Over $9^{8}$ percent of intercontinental Internet and telecommunication traffic passes through a network of fibre-optic cables. These submarine cables, which

sites should the Convention Parties adopt a procedure for nominating areas in ABNJ. See IUCN, 'Sargasso Sea Among Spots in the High Seas Identified as Potential World Heritage Sites' (3 August 2016), https://www.iucn.org/news/world-heritage/2016o8/ sargasso-sea-among-spots-high-seas-identified-potential-world-heritage-sites\#.

109 See Unesco, 'Linking the UN Decade of Ocean Science and the New UN Agreement on the High Seas' (18 April 2018), http://www.unesco.org/new/en/member-states/single view/news/linking_the_un_decade_of_ocean_science_and_the_new_un_agreem/; UNEsco, 'Roadmap for the UN Decade of Ocean Science for Sustainable Development' (13 July 2018), http://www.unesco.org/new/en/member-states/single-view/news/roadmap for_the_un_decade_of_ocean_science_for_sustainable_d/. 
are the diameter of a thumb in size, are vital to communications and commerce and are of socio-economic value. ${ }^{110}$ The laying and placement of submarine cables requires coordination, as cable installation may have adverse impacts on cables already in place, as well as on fishing, navigation, the marine environment, and other valuable resources, such as historic shipwrecks or areas of ecological or geological research. ${ }^{111}$ Unlike shipping or aviation, no inter-governmental agency is in charge of overseeing the submarine cablelaying industry. ${ }^{12}$ However, the ICPC is a non-profit organization dedicated to the protection and security of international submarine cables, including telecommunication, power, and scientific cables. The ICPC was created in 1958 to be 'the premier international submarine cable authority providing leadership, knowledge and guidance on issues related to submarine cable security and reliability'.13 The ICPC has 170 members from over 65 countries and covers over 97 percent of submarine cables.

110 UNGA, Resolution 71/257, above (n 51), para 168 (calling upon States to take measures to protect fibre-optic submarine cables), para 169 (encouraging greater dialogue and cooperation through workshops and seminars to promote the security of this critical communications infrastructure); see also International Cable Protection Committee (ICPC), Submarine Cables and BBNJ: Preparatory Committee established by UNGA, Resolution 69/292: Development of an internationally binding instrument under the United Nations Convention of the Law of the Sea on the conservation and sustainable use of marine biological diversity of areas beyond national jurisdiction (ICPC, 2016), http://www.un.org/depts/ los/biodiversity/prepcom_files/ICC_Submarine_Cables_\&_BBNJ_August_2016.pdf.

111 See L Carter, D Burnett, S Drew et al., Submarine Cables and the Oceans: Connecting the World, UNEP-WCMC Biodiversity Series No 31 (UN Environment Programme (UNEP) World Conservation Monitoring Centre, 2009) 3, noting the need for special care in areas of ecological or biological significance; also noting that submarine cable protective zones may have ancillary environmental benefits because of the prohibition of bottom trawling and use of other gear disturbing the seabed.

112 Only one regional body has addressed cable installation activities in ABNJ. The Commission of the Oslo/Paris Convention for the Protection of the Marine Environment of the North-East Atlantic (OSPAR Commission) has developed an EIA and non-binding guidelines for minimizing potential environmental harm associated with cable installation. Key guideline components are to (1) avoid protected and environmentally sensitive or valuable areas, (2) use the shortest possible length, (3) bundle existing cables and pipelines where safe, and (4) minimize cable-cable and cable-pipeline crossings. OSPAR Commission, Assessment of the Environmental Impacts of Cables (2009), https://www.gc. noaa.gov/documents/2017/poo437_Cables.pdf; OsPAR Commission, Guidelines on Best Environmental Practice (BEP) in Cable Laying and Operation, Agreement 2012-2, OsPAR Doc 12/22/1, Annex 14, https://www.gc.noaa.gov/documents/2017/12-o2e_agreement_ cables_guidelines.pdf.

113 ICPC, 'About the ICPC: ICPC Achievements' (15 November 2019), https://www.iscpc.org/ about-the-icpc/achievements/?print. 
In the wake of the Hamilton meeting in March 2014, the SCC was approached by the ICPC. In October 2014, they co-hosted a workshop, Submarine Cables in the Sargasso Sea: Legal and Environmental Issues in Areas beyond National Jurisdiction. The workshop report has been published ${ }^{114}$ and discusses 'best practices',115 noting that, in most cases, the laying of individual cables has minimal impacts on the deep seafloor. ${ }^{116}$ As another example of the ssc's groundbreaking efforts to directly engage with the commercial stakeholder community, the ICPC is now a Collaborating Partner with the ssC. This collaboration is important because, as noted in the report, there is no legal requirement for the individual ICPC members to conduct environmental impact assessments (EIAS) or otherwise address the concern of biological diversity in the ABNJ. As explored further below, regulations for EIAs and wider scale programmatic strategic environmental assessments (SEAs) that address the potential for cumulative impacts is another important role for the BBNJ agreement.

\subsection{Conservation of Migratory Species}

The Sargasso Sea is essential habitat for a number of migratory species, including turtles, whales, and eels throughout their respective ranges. ${ }^{117}$ Already there are concerns about the declining, threatened and endangered status of many of these species due to overfishing, bycatch, prey depletion, habitat degradation,

114 D Burnett, D Freestone and T Davenport, Submarine Cables in the Sargasso Sea: Legal and Environmental Issues in Areas beyond National Jurisdiction: Workshop Report (George Washington Law School, 16 January 2015), http://www.sargassoseacommission.org/ storage/documents/Submarine_Cables_in_the_Sargasso_Sea_Final_Workshop_Report_ dated_16_January_2015.pdf.

115 The ICPC provides guidelines for 'best practices' for laying cables on the seafloor through their issued ICPC Recommendations, especially Recommendation No. 17 recommending 'due diligence' in the laying of submarine cables. See ICPC Recommendation No. 17: Submarine cable operations in deep seabed mining concessions designated by the International Seabed Authority, adopted 31 May 2017, 4. (Recommendations are only available on request through https://www.iscpc.org/publications/recommendations/.) An ICPC Recommendation is only 'a consensus of those substantially concerned with its scope and provisions. A Recommendation is intended as a guide to aid cable owners and other seabed users in promotion of the highest goals of reliability and safety in the submarine cable environment'. Ibid 2.

116 AL de Juvigny, TM Davenport, DR Burnett and D Freestone, 'Submarine Telecommunications Cables in the Sargasso Sea' (2015) 30 International Journal of Marine and Coastal Law 371-378 (summary of the report); Burnett et al., Submarine Cables in the Sargasso Sea, above (n 114).

117 Laffoley, Roe et al., above (n 16), iii-iv. Many of the species that frequent the Sargasso Sea are listed on the IUCN Red List, and/or in the appendices of CITES, above (n 23), or in the annexes of the 1990 SPAW Protocol, above (n 23). 
chemical, noise and plastic pollution and ship strikes. An increasing concern is that the migratory patterns, oxygen levels and food supply of various species may differ with changes in ecosystems due to climate change. ${ }^{118}$

To advance the ssc's goals of obtaining international recognition of the significance of the Sargasso Sea to migratory species and facilitating proposals for their protection, the SsC under the leadership of David Freestone has been promoting a more active role for the $\mathrm{CMS}^{119}$ in $\mathrm{ABNJ}$ as well as working with existing institutions and State initiatives. In this he had the unwavering support of his long-time friend and immensely talented colleague, Dr Bradnee Chambers, the CMS Executive Secretary, who tragically died in January 2019 at the age of 53 after a short illness. ${ }^{120}$ At present, the CMS covers over a hundred marine species in its Appendices, mostly marine mammals, but also marine turtles and fish. ${ }^{121}$

\subsubsection{Conservation of Sea Turtles}

The Sargasso Sea is essential habitat for several endangered or threatened migratory sea turtle species, including green turtles (Chelonia mydas), hawksbill turtles (Eretmochelys imbricata), loggerhead turtles (Caretta caretta), and Kemp's ridley turtles (Lepidochelys kempii). ${ }^{122}$ The hatchling and juvenile stages of several species of turtles that nest on the beaches of the Caribbean and the Americas use Sargassum weed for hiding and feeding, spending their so-called 'lost years' amongst the weed. They rely on Sargassum for food, as a nursery, and as habitat or cover from predators.

118 See CMS, Migratory Species and Climate Change: Impacts of a Changing Environment on Wild Animals (UNEP/CMS Secretariat, 2006), https://www.cms.int/en/publication/ migratory-species-and-climate-change.

1191979 Convention on the Conservation of Migratory Species of Wild Animals (CMs), 1651 UNTS 333, Art IV(1). The objective of the CMS is to conserve wild migratory species throughout their range including the marine environment.

120 CMS, 'Bradnee Chambers 1966-2019' (23 January 2019), https://www.cms.int/en/news/ bradnee-chambers-1966-2019.

121 Migratory species threatened with extinction are listed on Appendix I of the Convention. CMS Parties strive towards strictly protecting these animals, conserving or restoring the places where they live, mitigating obstacles to migration and controlling other factors that might endanger them. Besides establishing obligations for each State joining the Convention, CMS promotes concerted action among the Range States of many of these species. Migratory species that need or would significantly benefit from international cooperation are listed in Appendix II of the Convention. For this reason, the Convention encourages the Range States to conclude global or regional Agreements. See CMS, 'Species List', https://www.cms.int/en/species?field_species_class_tid=454.

Laffoley, Roe et al, above (n 16), 2 . 
The threats to these species include loss of habitat, direct loss through overexploitation of turtles and eggs, and an even greater direct loss through their incidental take in commercial fishing activities. ${ }^{123}$ In 2014, the SSA initiated cooperation with the Secretariat of the Inter-American Convention (IAC) for the Protection and Conservation of Sea Turtles. ${ }^{124}$ The Secretariats of the IAC and ssc collaborated on a joint information paper recognizing the importance of Sargassum and the Sargasso Sea for the conservation of Atlantic sea turtles. This paper shows important turtle migration links between the Sargasso Sea, the islands of Bermuda, the Caribbean Sea, and migratory routes through the Atlantic Ocean to many of the States of the Latin American Organization for Fisheries Development, including Belize, Costa Rica, Cuba, El Salvador, Guyana, Honduras, Mexico, and Nicaragua. ${ }^{25}$ It is States Parties to ICCAT, however, who are in the best position to adopt the requisite conservation measures to reduce bycatch in ABNJ of these critically endangered species as ICCAT measures would be applicable to distant water fishing States as well.

123 M Solano, S Troëng, C Drews and B Dick, Inter-American Convention for the Protection and Conservation of Sea Turtles: An Introduction (IAC Secretariat, September 2004) 7, http://www.iacseaturtle.org/eng-docs/publicaciones/The-Inter-American-ConventionAn-Introduction-(hires).pdf. Necropsies of 107 turtles found dead on the Pacific beaches of Costa Rica reveal that the 81 percent of the deaths were caused by fish hooks; entanglement in nylon line and fishnets; ventral incisions to obtain eggs and meat; and fractures and cranial trauma sometimes caused by collision with boat motor propellers. The other 19 percent died of natural causes, mainly from predation by crocodiles, coyotes, and sharks (citing см Orrego, Causas naturales y antrópicas en la mortalidad de las tortugas marinas en el Pacífico de Costa Rica, Tesis de Maestría en Manejo y Conservación de Vida Silvestre, Programa Regional en Manejo de Vida Silvestre, Univ. Nacional, Heredia, 2002).

124 The 1996 Inter-American Convention for the Protection and Conservation of Sea Turtles (IAC) (2164 UNTS 29, in force in 2001), has fifteen parties. The IAC was initially proposed by the Latin American Organization for Fisheries Development (oldepesca) and various governments of the western hemisphere to establish appropriate measures for the protection of sea turtles and the conservation of their habitats throughout the Americas. The IAC's primary goal is to 'promote the protection, conservation and recovery of sea turtle populations and the habitats on which they depend, based on the best available scientific evidence, taking into account the environmental, socio-economic and cultural characteristics of the Parties'. OLdepesca was constituted under the 1982 Convention Instituting the Latin American Organization for Fisheries Development (OLDEPESCA) (1427 UNTS 133).

125 IAC and SSA, 'Concept Note on the Importance of Sargassum and the Sargasso Sea for Atlantic Sea Turtles', CIT-CCE7-2014-Doc 3 (2014), http://www.sargassoseacommission. org/publications-and-news/sargasso-sea-commission-reports. The Sargasso Sea ecosystem and Bermuda are key habitat for conservation of sea turtles. An ssc proposal for an memorandum of understanding with the IAC was opposed by Argentina. 


\subsubsection{Conservation of Whales}

Thirty species of whales are found in and throughout the Sargasso Sea. Humpback whales (Megaptera novaeangliae) make regular migrations through the area en route from the Caribbean to the northern North Atlantic. The area around Bermuda is an important part of the humpbacks' journeys to and from the northern feeding grounds and their southern calving and breeding grounds. In 2011, the sSA commissioned a study from the Humpback Whale Research Project in Bermuda ${ }^{126}$ that showed that the Sargasso Sea, mid-ocean seamount habitats, and Bermuda are not simply navigational waypoints, but are actually key to the survival of humpback whales. On 21 September 2012, Andrew Stevenson (of the Humpback Whale Research Project) and Freestone stood next to Minister Marc Bean MP JP when he declared the Bermuda EEz to be a Marine Mammal Sanctuary. ${ }^{127}$

The ssA, through its contacts with US NOAA, facilitated the signing of a 'Sister Sanctuary' Agreement between NOAA's Office of National Marine Sanctuaries and the Bermuda Ministry of Environment, Planning, and Infrastructure Strategy on 27 September 2012. The Signatories agreed to cooperate on scientific and educational programs to better protect the endangered humpback whale between the Stellwagen Bank National Marine Sanctuary - off the coast of Massachusetts where the humpback whales come to feed in the summer and Bermuda. ${ }^{128}$ The United States has a similar sister sanctuary relationship with the Silver Bank Sanctuary in the Dominican Republic, which is a calving and breeding area. Bermuda, nearly $65^{\circ}$ miles east of the North Carolina coast, is strategically situated between these areas. These sister sanctuary partnerships could enhance the three nations' efforts to protect the species

126 A Stevenson, Humpback Whale Research Project, Bermuda, Sargasso Sea Alliance Science Report Series No 11, (SSA, 2011), http://www.sargassoseacommission.org/storage/documents/No.11_WhaleResearch_HI.pdf.

127 http://www.sargassoseacommission.org/storage/documents/bermuda_ssfs12.pdf C Wilson, 'Marine Sanctuary Declared for Marine Mammals' The Royal Gazette (21 September 2012), https://www.royalgazette.com/other/news/article/20120922/marinesanctuary-declared-for-marine-mammals/.

128 The United States listed all humpback whales as endangered under the Endangered Species Act (ESA) in 1973. The International Whaling Commission's whaling moratorium, in effect since 1985 , played a major role in the comeback of humpback whales. Currently, under the US Endangered Species Act, four out of the fourteen distinct population segments are still protected as endangered, and one is listed as threatened. Under CiTES, above (n 23), the humpback whale is listed under Appendix I (most endangered) throughout its range. See NOAA Fisheries, 'Humpback Whale: Overview', https://www.fisheries.noaa.gov/species/humpback-whale; see also Cites, 'Appendices I, II and III', https://www.cites.org/ eng/app/appendices.php. 
at various points within its migratory route. This interdependence highlights the significance of the network of protected sites to humpback whales but also the potential exposure of the whales while passing through the connecting corridors.

\subsubsection{Conservation of Eels}

Eels are living fossils that can be traced back hundreds of millions of years ago, predating even the dinosaurs. The efforts and accomplishments of Freestone and the SsC on eels is important for the eels' conservation, and also for underscoring the importance of conserving all species, even the traditionally less charismatic ones, and for taking an ecosystem approach that considers all impacts and stressors. The European eel (Anguilla anguilla) and the American eel (A. rostrata) are endangered, and the European eel is critically endangered. ${ }^{129}$ Both species are catadromous, spending most of their life stages in freshwater habitats or 'continental waters', and both return to the open ocean to spawn in the North Atlantic Subtropical Gyre around the Sargasso Sea. ${ }^{130}$ While the eel is known to be depleted, less is known about its complex life cycle beyond the central importance of the Sargasso Sea in the spawning cycle.

In the spring of 2014, the SSA commissioned a science report ${ }^{131}$ to support the listing of the European eel under CMS Appendix II. Such a listing is appropriate if the species has an 'unfavourable conservation status' and if its conservation status 'would significantly benefit from the international cooperation that

129 See IUCN Red List, 'European Eel, Anguilla anguilla', http://www.iucnredlist.org/details/ 60344/o;; IUCN Red List, 'American Eel, Anguilla rostrata', http://www.iucnredlist.org/ details/191108/o.

130 'There are still no exact data about specific spawning sites, however, from, and building upon, work carried out by Johannes Schmidt in the early part of the 2oth Century it has been deduced that spawning takes place in an elliptic zone, about 2,00o $\mathrm{km}$ wide in the Sargasso Sea, in the West Central Atlantic (approximately centred around $26^{\circ} \mathrm{N} 60^{\circ} \mathrm{W}$ ). It should be noted that the American eel (Anguilla rostrata) is believed to spawn in a sympatric area of the Sargasso Sea. Surveys of A. anguilla leptocephali indicate that spawning peaks in early March and continues to July and that they are <10mm upon hatching. Spent adults are assumed to die after spawning'. cms, Proposal for the inclusion of the European eel (Anguilla anguilla) on CMS Appendix II, Doc UNEP/CMS/COp11/Doc.24.1.18 Rev.1 (12 September 2014) 3 (references omitted). See more recently, MJ Miller, H Westerberg, H Sparholt et al., 'Spawning by the European Eel Across 2000 km of the Sargasso Sea' (2019) 15 Biology Letters 20180835, https://doi.org/10.1098/rsbl.2018.0835.

131 CMS, Proposal for inclusion of the European eel (Anguilla anguilla) in CMs Appendix II, UNEP/CMS/ScC18/Doc.7.2.18 (11 June 2014), submitted to the Scientific Council by the Government of Monaco in cooperation with the Sargasso Sea Alliance, based on work by Dr M Gollock and Dr D Jacoby. 
could be achieved by an international agreement. ${ }^{\prime 32}$ The Government of the Principality of Monaco, as a signatory to the Hamilton Declaration in March 2014, agreed to put forward the report on behalf of the Commission, first to the CMS Science Council, ${ }^{133}$ and subsequently to the CMS 11th Conference of the Parties (COP 11) in Quito in November 2014, where it was approved. ${ }^{134}$

The ssc has since sponsored several expert workshops and meetings on eels. In October 2015, the SSC sponsored an American Eel Symposium in Portland, Maine ${ }^{135}$ that convened over thirty eel experts and stakeholders from government, academia, commercial, and conservation interests to review key scientific, policy, and cultural issues surrounding the American eel. ${ }^{136}$ The First Range States Workshop on the European Eel was later held 13-14 October 2016 in Galway, Ireland, in partnership with the Secretariat of the CMS, the IUCN Anguillid Eel Specialist Group (AESG), and the Zoological Society of London. ${ }^{137}$ The workshop brought together representatives of ten range States and the European Union, members of the Secretariats, and international eel experts from North America and a wide range of European countries. These representatives discussed the European eel's conservation and management and considered whether there was a potential role for the CMS in relation to its conservation, as the 1972 CMS envisions the development of conservation instruments for specific migratory species under its auspices. ${ }^{138}$ The meeting

132 CMS, above (n 119), $\operatorname{Art~IV(1).~}$

133 UNEP/CMS/ScC18/Doc.7.2.18, above (n 131), was submitted as Proposal II/12 at the 18 th Scientific Council meeting, 1 July 2014.

134 UNEP/CMS/COP11/Doc.24.1.18.Rev.1, above (n 130).

135 SSC sponsored the Symposium along with the Marine \& Environmental Law Institute of Dalhousie University, Ocean Tracking Network, Social Sciences and Humanities Research Council of Canada, Center for Oceans and Coastal Law at the University of Maine School of Law, Ocean and Coastal Law Journal, and the Gulf of Maine Research Institute. See SsC, 'About Our Work: Sargasso Sea Commission Sponsors an American Eel Symposium in Portland, Maine', http://www.sargassoseacommission.org/about-our-work/workshops/ american-eel-workshop.

136 The Ocean and Coastal Law Journal at Maine Law School published a symposium journal summarizing the proceedings of the conference. D Freestone, C Norchi and D VanderZwaag, 'American Eel: A Symposium. Introduction' (2016) 21 Ocean and Coastal Law Journal 1, http://digitalcommons.mainelaw.maine.edu/oclj/vol21/iss1/2.

137 CMS, Report of the First Range States Workshop on the European Eel, Doc UnEP/CMS/ Eels ws1/Report (2016), http://www.sargassoseacommission.org/storage/documents/ cms_eels_ws1_meeting-report-outcomes.pdf.

138 These conservation instruments can be treaties, such as the Ассовамs and Asсовамs agreements on cetaceans or the Wadden Sea Seals Agreement. These instruments can also be memoranda of understanding (MOU), as with the MOUs on the Conservation of Migratory Sharks or the Conservation of Dugongs. See Agreement on the Conservation of Cetaceans of the Black Seas, Mediterranean and Contiguous Atlantic Area, adopted 
recognized a possible role for a CMS instrument and recommended a further meeting be held and attended by policy makers and scientists with a wider representation of the more than fifty range States. This recommendation was followed up by a Concerted Action proposal that was approved by the 2017 CMS COP 12 in Manila. ${ }^{139}$ The Concerted Action decision approved the idea of a second meeting held in 2018 'with broader participation from range States including those from outside the EU'.140

For the Second Range States Workshop on the European Eel, the SsC partnered with the Secretariat of the CMS and the World Maritime University (WMU) to host a workshop at WM U's headquarters in Malmö, Sweden, between 15 and 16 May 2018. This meeting provided an opportunity for representatives of twenty-three range States, the European Union, and representatives from virtually all of the relevant international organizations, including the International Council for the Exploration of the Sea (ICES), Convention on International Trade in Endangered Species of Wild Fauna and Flora (CiTES), General Fisheries Commission for the Mediterranean (GFCM), HELCOM, and $\mathrm{AESG}^{141}$ to review the European eel's conservation and management. The meeting specifically identified the need for international co-operation to protect the eels' spawning site in the Sargasso Sea, and after extensive discussions

24 November 1996, in force 1 June 2001, http://accobams.org/; Agreement on the Conservation of Small Cetaceans in the Baltic, North East Atlantic, Irish and North Seas, adopted 17 March 1992, in force 29 March 1994, http://www.ascobans.org/; Agreement on the Conservation of Seals in the Wadden Sea, adopted 16 October 199o, in force 1 October 1991, http://www.waddensea-secretariat.org/management/seal-management; CMS, Memorandum of Understanding on the Conservation of Migratory Sharks, adopted 12 February 2016, in force 1 March 2010, https://www.cms.int/sharks/en/page/sharks-moutext; CMs, Memorandum of Understanding on the Conservation and Management of Dugongs (Dugong dugon) and their Habitats throughout their Range, adopted and in force 31 October 2007, https://www.cms.int/dugong/en/page/mou-text.

139 CMs, Concerted action on the European eel (Anguilla anguilla), adopted by the Conference of the Parties at its 12th meeting (Manila, October 2017), Doc UNEP/CMS/ Concerted Action 12.1.

140 The decision sought to survey range States to identify conservation and management gaps and encouraged cooperation with other relevant organizations like ICES, AESG, Cites, and regional fisheries bodies, including the General Fisheries Commission for the Mediterranean.

141 Helcom is the Secretariat of the Helsinki Commission for the Baltic Sea. See Helcom (Baltic Marine Environment Protection Commission) website, http://www.helcom.fi/. In November 2017, SSC collaborated with CMS and HELCOM in the sponsorship of a meeting of Baltic range States on the European eel. See ssc, 'Regional Workshop on Eel and the Baltic Sea', http://www.sargassoseacommission.org/about-our-work/workshops/ regional-workshop-on-eel-and-the-baltic-sea. 
of the comparative advantages of the CMS, decided that there is a potential for international cooperation to address gaps and challenges in European eel conservation. ${ }^{142}$ It was agreed that the CMS, as a global mechanism, could address many of these issues and that the CMs, in association with the SsC, would begin discussions on the modalities of setting up such a mechanism for more coordinated and comprehensive European eel conservation, including specific protections for the spawning sites in the Sargasso Sea. ${ }^{143}$ This is a very significant mandate for the CMS and the SsC to draw on all mechanisms available under international law to protect the eel spawning areas in the Sargasso Sea. ${ }^{144}$

The Third Range States Workshop on the European Eel was again a partnership between the ssc, WMU and the Secretariat of the CMS from $25^{-26}$ June 2019 in Malmö, Sweden, with support from the Principality of Monaco. The meeting highlighted the urgent need to do more to protect the species' critically endangered population. Twenty-four range States including the European Union, as well as FAO, Cites, WMU, HELCOM, AESG, GFCM and NGO s attended the meeting. Participants discussed the need for greater transboundary cooperation, especially between EU countries and those outside the bloc. The potential role that CMS could play in this, working closely with other forums such as those mentioned above was recognized.

Experts and Range States outlined the main threats facing the species and elaborated possible areas for action which could be undertaken within the CMS context. Rather than a legally binding agreement, many participants

142 See the outstanding paper prepared for the ssc by Professor Chris Wold and presented at the Second Meeting of Range States for the European Eel: Malmö, Sweden, 15-16 May 2018: C Wold, Options for Developing an Agreement under the Convention of Migratory Species for European Eels, Doc UNEP/CMs/Eels2/Doc.7.1 (2018), https://www.cms.int/ sites/default/files/document/cms_eels2_doc.7.1_options-for-developing-an-agreementunder-cms-for-european-eels_e_o.pdf.

143 CMs, Concerted Action, above (n 139).

144 Ibid. The ssc Secretariat, with the support of the US Fish and Wildlife Service and Department of Fisheries and Oceans Canada, also convened a successful American Eel Range States Workshop, in Santo Domingo, Dominican Republic, 4-6 April 2018. This ssc-partnered meeting was designed to feed information on the status and management of eel stocks in the Caribbean and Gulf of Mexico into coordinated proposals for the 3oth Meeting of the CiTes Animals Committee planned for 16-21 July 2018. The Meeting, attended by eleven Range States, recognized the pressure on the American eel from, inter alia, international trade and recommended regional cooperation to address these issues. CITES, Report of the Workshop of Range States of the American Eel, Thirtieth meeting of the Animals Committee Geneva (Switzerland), 16-21 July 2018, http://www.sargassoseacommission.org/storage/FINAL_REPORT.pdf. 
were in favour of developing a Single Species Action Plan for the species, while remaining open to the idea of extending the scope of any conservation initiative to other anguillid species, such as the American eel (A. rostrata). States opted for a stepwise approach to move forward, requesting the cMs Secretariat and/or interested Range States to bring a document charting a possible way forward to CMS COP13, in February 2020. ${ }^{145}$

\subsection{The ssc's Role in Advancing Data and Information Management}

There are significant challenges in conserving large marine areas in the high seas as well as within EEzs. ${ }^{146}$ One of these is gathering the available data. In addition to the early studies on the Sargasso Sea, the principal activity of the ssc concerning the data and information priority work area is the invaluable collaboration with NASA. This NASA collaboration has been aimed at developing a multidimensional mapping tool for the Sargasso Sea with the assistance of key marine researchers and scientists including those at the Jet Propulsion Laboratory, Bermuda Institute for Ocean Science and Duke University's Marine Geospatial Ecology Lab. This mapping pilot project has the potential to allow users to access and visually display relevant data of their choosing by combining NASA satellite observation data of oceanographic conditions, such as currents, temperature, salinity, chlorophyll, and possibly seaweed presence and movement, with data on commercial, recreational, ecological, and biological uses of the sea. In April 2017, at its meeting in Paris, the International Committee on Earth Observation Satellites (CEOS-SIT32) so strongly endorsed this pilot initiative that it is now called the CEOs Ocean Variables Enabling Research and Applications for Geo (COVERAge). ${ }^{147}$ Freestone serves on the

145 Summary of meeting from ssc, 'Third Range States Workshop on the European Eel', http://www.sargassoseacommission.org/about-our-work/workshops/third-range-states -workshop-on-the-european-eel.

146 See D Freestone, O Varmer, M Bennett et al., 'Place-based Dynamic Management of Large-scale Ocean Places: Papahānaumokuākea and the Sargasso Sea' (2014) 33 Stanford Environmental Law Journal 191-248 (case study comparing and contrasting efforts to protect the Papahānaumokuākea Marine National Monument, a very large MPA in the EEZ off Hawaii and the Sargasso Sea ecosystem). The Papahānaumokuākea case study represents what can be done using national law in coordination with international law requirements to protect a large ocean space. At that site, various boards, advisory councils, and committees brought in federal, state, and local stakeholders, which is also a possible model for how to bring together similar sectoral interests in order to accomplish integrated marine planning in a large area of the ocean.

147 The Committee on Earth Observation Satellites' (CEOS) mission statement is 'to develop a more seamless approach for delivering remote sensing data, including near realtime data streams, and that are better integrated with in-situ datasets in support of oceanographic and decision support applications for societal benefit'. See generally, E 
Advisory Committee of this important and exciting international three-year initiative demonstrating how satellite data can be used at a regional level, possibly even for ocean management. ${ }^{148}$

\section{Summary of Lessons Learned from the Innovative Governance of the Sargasso Sea}

From history we have learned that an individual can lead a small group of concerned citizens and eventually change the world. It may start as a dream but with patience, passion and persistence, a change for the better is within reach. Freestone, in his leadership role with the Sargasso Sea Alliance and now the ssc, has shown the importance of individuals in advancing the frontiers of high seas governance to safeguard significant and vulnerable ocean spaces beyond national jurisdiction. While Freestone is an expert in law by training and practice, his reliance on science and patience with the process of international law and policy is his true genius. By drawing heavily on the science and scientific communities, Freestone has been able to gain legitimacy, credibility and convening power, which in turn served to build the capacity of a wide range of bodies that otherwise lacked time or funds to do the scientific work. By making extensive use of networks, Freestone has expanded the reach of the Sargasso Sea initiative way beyond its small size.

As the leader of a small but professional Secretariat, ${ }^{149}$ Freestone brought together ten governments, seven expert Sargasso Sea Commissioners, and a widening array of collaborating partners to foster the stewardship of the Sargasso Sea. Together they have catalysed international recognition of the significance of the Sargasso Sea as an ESBA and a potential World Heritage Site, stimulated cooperation for the protection of European eels through their listing under the CMS and the recent mandate to provide protection for the eels' spawning areas, and accelerated action by NAFO to protect seamounts from bottom fishing and midwater trawling. In a world in sore need of scientific

Lindstrom, V Tsontos and J Vazquez, 'The cEos Ocean Variables Enabling Research and Applications for GEO (COVERAGE) Initiative: Status Overview', presentation to SIT Tech Workshop, 13-14 September 2017, http://ceos.org/document_management/Meetings/ SIT-Technical-Workshop/2017-SIT-Tech-Workshop/VC-WG-Side-Meeting/SITTWS2O17_ COVERAGEpresentation_FINAL_20170831\%5B2\%5D.pptx.

148 Ibid.

149 With the excellent support in the early stages from Kate Killerlain Morrison (2011-2014), later Faith Bulger (2015-2017), and currently Teresa Mackey (2017-to the present). 
information on habitats and ecosystems associated with the deep and distant high seas environment, the SSC has amassed a wealth of scientific information on the Sargasso Sea and made it available to all, including, most recently, through the COVERAGE project in cooperation with NASA and the pelagic food web analysis for tuna and non-tuna species for ICCAT. ${ }^{150}$ Partnerships with ongoing scientific initiatives such as Migratory Connectivity in the Ocean (MiCO) are fostering new ways to obtain and synthesize data. The Sargasso Sea initiative is filling a gap.

However, as noted earlier, NAFO's closure of several seamounts to deep sea bottom fishing in 2017 is a temporary closure that will expire in $2020 .{ }^{151}$ The need for constant reaffirmation of protective measures, which may be defeated by the objection of one member, is not a comforting way to secure long-term protection of seamount ecosystems whose recovery may take decades to centuries, if at all. ICCAT has made progress in its science-based recognition of the importance of the Sargasso Sea to tuna and tuna-like species but is having difficulty implementing a precautionary and ecosystem-based management approach in its decision-making. Member States at the Imo have not yet officially recognized the importance of the Sargasso Sea by designating or utilizing their existing powers for mitigating the environmental impacts of shipping. This has led the SsC to redirect its efforts to work more directly to generate interest within the international shipping community and the public. At the ISA, which has been represented at SSC meetings and has authorized the SSC to attend ISA meetings, the challenge remains how to ensure that exploration and any future exploitation of seabed minerals do not adversely impact the Sargasso Sea and other significant biologically diverse areas in ABNJ, in implementation of the ISA's mandate to ensure effective protection of the marine environment. The SSC has made much progress cooperating with the ICPC. However, since the ICPC is a private entity, there is no international governmental oversight of cable laying in ABNJ. And while there appears to be an assumption that there are little or no adverse environmental effects from laying cables in the ABNJ, only privately held technical feasibility reviews, rather than publicly available EIAs, are conducted. Thus, there is no opportunity to consider the potential for overlap, conflicting uses or cumulative effects. The sSC's innovative cooperation with the ICPC and other commercial use sectors

150 See Luckhurst and Arocha, above (n 86).

$15^{1}$ See F Kingston (NAFO Executive Secretary), 'Future Collaboration regarding Human Impacts on the Sargasso Sea Fisheries', presentation to Next Steps to Strengthen Stewardship of the Sargasso Sea Workshop, Bermuda, 14 March 2019, http://www.sargassoseacommission.org/storage/2019_03_14__NAFO_--_Sargasso_Sea_workshop.pdf. 
clearly needs to continue, as does its work with sectors focused on marine species, ecosystem, habitat, and biodiversity conservation.

Notwithstanding the ssc's impressive achievements, the remaining challenges demonstrate the limits to what an individual, or a small number of committed individuals, scientists and government representatives, can do in terms of fostering stewardship and integrated management of ecosystems beyond national boundaries. As the mechanisms and processes of sectoral institutions continue to be limited, the work of the SsC is shining a light on the need for a new, holistic approach based on science, precaution, and effectively coordinated and integrated management of marine areas in ABNJ. ${ }^{152}$

The ssc experience also provides evidence of the need for a global level agreement to address the strong force of inertia against more progressive conservation, despite calls for the application of the best available science, the adoption of a precautionary principle in many modern international legal instruments and declarations and commitments to applying a precautionary approach. ${ }^{153}$ The lack of recognition by one sector of the work of another is an unfortunate example of how the fractured sectoral approach appears to be undermining efforts to utilize the precautionary principle and protect areas of significant biodiversity. ${ }^{154}$ It also demonstrates the need for a mechanism to consider cumulative impacts from different sectors and the aggravating factor of climate change. ${ }^{155}$ Together it illustrates the need for structures and processes that are designed to ensure accountability, transparency, responsiveness, rule of law, stability, equity and inclusiveness, empowerment, and broad-based participation across the global ocean and at the regional level.

A Way Forward: Navigating Towards Conservation of Biodiversity in the ABNJ

In light of the lessons and limitations described above, the importance of the UN negotiations for a binding international agreement for the conservation and sustainable use of marine biodiversity beyond national jurisdiction is clear: in order to achieve its biodiversity objectives, the global agreement will

\footnotetext{
$15^{2}$ See Freestone and Gjerde, Lessons, above (n 11).

153 See Freestone and Harris, above (n 102).

154 See ibid.

155 Ibid.
} 
need to redress fundamental weaknesses and gaps in high seas governance. To achieve this aim, key elements for the ввNJ agreement ${ }^{156}$ could include:

- First, reaffirm in its provisions on Principles and Approaches (currently in Part 1, Article 5) the modern principles of ocean governance, like the precautionary approach and ecosystem-based management, transparency, stewardship and public participation. ${ }^{157}$

- Second, craft provisions on area-based management tools and EIAs (currently in Parts 2 and 3) to operationalize global commitments such as the Sustainable Development Goals and the Aichi Targets as obligations to prevent pollution, manage activities to strengthen ecosystem resilience and avoid significant adverse impacts, as well as to cooperate in establishing networks of marine protected areas and other area-based management tools.

- Third, clarify, in a new Part on General Obligations, the duty of States Parties to act directly and through existing (and any new) organizations to protect and preserve the marine environment and conserve its biodiversity through, inter alia, regional environmental assessments and strategic environmental assessments to inform and underpin area-based management tools including marine spatial planning, ${ }^{158}$ M PA networks, ${ }^{159}$ as well as EIAs and more

${ }_{15} 6$ See UNGA, Resolution 72/249: International legally binding instrument under the United Nations Convention on the Law of the Sea on the conservation and sustainable use of marine biological diversity of areas beyond national jurisdiction, adopted 24 December 2017.

157 Freestone, Modern Principles, above (n 9), 44-49.

158 Marine spatial planning (MSP) requires establishing 'appropriate authority' for both planning and implementation. There is currently no such authority in ABNJ. V BeckerWeinberg, 'Preliminary Thoughts on Marine Spatial Planning in Areas beyond National Jurisdiction' in D Freestone (ed), Conserving Biodiversity in Areas beyond National Jurisdiction (Brill, 2019); G Wright, KM Gjerde, DE Johnson et al., 'Marine Spatial Planning in Areas beyond National Jurisdiction' (2019) Marine Policy, https://doi.org/10.1016/ j.marpol.2018.12.003.

159 There is increasing demand for MPA creation, especially for larger MPAs and MPA networks. Large-scale MPA benefits include protection of entire ecosystems, creation of refuges for migratory species, a buffer for habitat shifts potentially occurring in the near future, and preservation of pristine areas for use as scientific baselines. N Lewis, JC Day, A Wilhelm et al., Large-Scale Marine Protected Areas: Guidelines for Design and Management, Best Practice Protected Area Guidelines Series No 26 (IUCN, 2017) 2; see generally, DM Ceccarelli, V Matoto, J Raubani et al., Biophysical Design Principles for Offshore Networks of No-Take Marine Protected Areas (Marine and Coastal Biodiversity Management in Pacific Island Countries, 2018), http://macbio-pacific.info/wp-content/ uploads/2018/04/MACBIO-BiophysicalDesignPrincipals-digital.pdf; see also, IUCN WCPA, 'Applying IUCN's Global Conservation Standards to Marine Protected Areas (MPA): Delivering effective conservation action through MPAs, to secure ocean health 
integrated, ecosystem-based and ecologically sustainable management across the region.

- Fourth, in its provisions for area based management tools and EIAs (currently in Parts 2 and 3), legally recognize areas that meet the criteria for EBSAs such as the Sargasso Sea as priority areas for coordinated action and enhanced protection. Such recognition could entail, for example, automatically requiring EIAs for activities in recognized EBSA s or in areas likely to meet such criteria, requiring the adoption of measures to avoid significant adverse impacts, and according such areas priority for spatial planning efforts, including MPAs, SEAs, integrated management and other area-based management tools.

- And fifth, call for States to cooperate to support and enable the science to underpin ecosystem-based management, to advance understanding of the pressures, drivers and stressors of oceanic changes as well as potential threats, to understand and protect sites of ecological, biological or other significance, and assist in developing and implementing an array of measures at all levels to enhance ocean health, productivity, and resilience in ABNJ.

To provide a mechanism to pursue these aims at a regional level, the new agreement could establish or designate regional bodies to enhance coordination and governance consistent with the new agreement, taking into consideration specific regional characteristics. As Freestone has elaborated more fully in a concept paper, 'Taking the Hamilton Declaration to the Next Level,', ${ }^{160}$ the role of ROGO s ${ }^{161}$ for places such as the Sargasso Sea could be recognized in the new agreement, akin to the way the UN Fish Stocks Agreement mandates and establishes baseline requirements for RFMO s. As noted by Freestone,

The idea of Regional Ocean Governance Organizations was promoted by the Global Oceans Commission. The negotiations for such a new regional ocean governance organization would complement the [international legally binding instrument (ILBI)] discussions, and may also help to demonstrate the limitations of a purely sectoral approach. Using

and sustainable development' (Version 1, IUCN, 2018) 3-4 (describing IUCN global conservation standards for MPAs, including those of good governance, sound planning and design, effective management, and conservation outcomes).

16o Freestone, 'Taking the Hamilton Declaration to the Next Level', above (n 12).

161 The Global Ocean Commission's 2014 report, From Decline to Recovery: A Rescue Package for the Global Ocean, called for the establishment of regional oceans management organizations. See also Global Ocean Commission, The Future of Our Ocean: Next Steps and Priorities (2016), both reports are at http://www.some.ox.ac.uk/research/global-oceancommission/download-reports/. 
the UN ILBI "package deal components" as the basis, it could set itself the goal of developing an integrated marine planning and ecosystem-based management system; it could (building on the existing and ongoing work of the Commission) sponsor a regional environmental assessment of the status and threats to the Sargasso Sea region, with the hopes of developing a regional biodiversity strategy and action plan with key players. It could bring in elements of marine spatial planning to develop options for separating conflicting uses, and for protecting the key elements of the ecosystem, through the use of protected areas. With a distinguished advisory body of scientific experts to assist member states in understanding the potential environmental implications of new and ongoing activities, it could develop a research and monitoring plan for supporting/coordinating marine science in the region and possibly promote the establishment of a regional center of excellence for marine biodiversity discovery, conservation and innovation, including links to a possible future system of access and benefit sharing.

The ввNJ agreement could clarify that RoGos - like other regional and sectoral organizations - would operate consistent with the agreement and the Convention. ${ }^{162}$ In other words, when fulfilling their obligations to protect and preserve the marine environment, they could be charged with complementing and enhancing existing legal instruments and frameworks and relevant global, regional, and sectoral bodies, such as RFMOs, the IMO, or the FAO. ${ }^{163}$ At the same time, the ROGOs should be given the authority to monitor and report shortfalls in compliance and implementation with the global agreement and the regional stewardship plan to a global conference of parties.

In these authors' view, such an integrated system of regional and global ocean governance may be what is necessary to break what appears to be a log jam for progress on the conservation of biodiversity in the ABNJ. Decades of a sectoral approach and uncoordinated scientific research have resulted in a lack of focus on protecting the marine environment and conserving biodiversity in ABNJ. At present regional bodies, whether regional seas organizations like OSPAR or partnerships such as the SSC and its Government Signatories, lack the ability to promote accountability, transparency, equity or broad-based participation in other organizations. The new global agreement presents an opportunity to level the playing field by creating a system where more specific

162 UNGA Resolution 69/292, above ( $\mathrm{n} 4)$.

163 See LosC, above (n 5), Arts 192, 195(4), 197. 
conservation obligations and common principles, standards and objectives apply to most if not all of the players - the parties to the new agreement. Such shared obligations, principles, standards and objectives can then help strengthen the governance processes and conservation outcomes of existing and any newly established bodies. The ROGO s could simultaneously serve the role of informing the conference of the parties to the new agreement on how to best move forward to address regional conservation interests - based upon improved scientific, economic, technical, and legal information - while benefitting from global leadership, reach and engagement as well as ideally financial support.

\section{A Way Forward for the Sargasso Sea Commission}

The Sargasso Sea Commission has already developed the elements of a major 'Stewardship Plan' for the high seas area. The ввNJ negotiations will hopefully provide a major impetus for conserving habitat and ecosystems around the world. We propose that, because of all the work over the past several years, the Sargasso Sea would be an excellent place to begin and that there is no need to await the completion of negotiations. Freestone's intellectual contributions and innovative initiatives through the Sargasso Sea Project over the past decade have paved the way.

As the international community convenes to develop an international agreement for the conservation of biodiversity in ABNJ, the SSC and its members could consider building on its work, the work of the sSA, and the lessons learned in building regional capacity to advance coordinated conservation activities. One timely option could be for the Signatories to the Hamilton Declaration to develop a legally binding agreement in tandem with the ввNJ process. As envisaged by Freestone and supported by the authors, development of such a legally binding agreement should not be viewed as a competing or conflicting effort, but rather as a way to see how the ssc may complement, if not directly help, the broader and more important efforts in the вв NJ process. A new regional agreement could establish a ROGO for the Sargasso Sea charged with overseeing the preservation and continued productivity of an entire ecosystem, as described above, rather than just managing a specific activity or resource.

As Executive Secretary, Freestone continues to expand the number of Signatories to the Hamilton Declaration (now ten), negotiate collaboration arrangements, such as memoranda of understanding, between the SSC and other international bodies, and, where appropriate, attain observer status with 
such bodies and arrangements with other collaborating partners, including RFMOs, while pushing the frontiers of international law through the ввNJ process, the CMS and the World Heritage Convention, and innovative ideas for advancing regional ocean governance. With its mission of stewardship and its support from leading international experts and Signatory Governments, the ssc is able to serve as an important voice for the Sargasso Sea. The Commission is pioneering a new way of doing business in high seas governance and it is gratifying to see that support for its work among governments, research institutions and international organizations is still growing as both number of Collaborating Partners and new Programmatic Partners continues to expand. ${ }^{164}$ The Sargasso Sea Commission website is the great way to keep up with this evolving process. ${ }^{165}$

164 Freestone and Bulger, above (n 10).

165 See http://www.sargassoseacommission.org/. 